\title{
Wśród uczniowskich i studenckich walet (z osiemnastowiecznej gdańskiej poezji okolicznościowej)
}

Edmund Kotarski 


\section{Edmund Kotarski}

\section{W'śód uczniowskich i studenckich walet (z osiemnastowiecznej gdańskiej poezji okolicznościowej)}

\section{Peregrinatio academica młodzieży gdańskiej}

$\mathrm{W}$

XVIII wieku młodzi gdańszczanie, podobnie jak ich siedemnastowieczni poprzednicy, po nauce w Gimnazjum Gdańskim wyruszali często na studia do stosunkowo blisko położonego Królewca, a także do innych miast uniwersyteckich, jak Rostock, Greifswald, Frankfurt nad Odrą, Halle, Jena, Lipsk, Wittenberga, Marburg, Getynga. Niektórzy korzystali ze stypendiów Rady Miasta i — niekiedy — prywatnych ${ }^{1}$. W tym miejscu warto dodać, że w XVIII wieku w dalszym ciągu istniało aerarium pro pauperibus studiosis. Wśród wspierających tę fundację były osoby prywatne, nie ujawniające niekiedy swego nazwiska. W „Wöchentliche Danziger Anzeigen und dienliche Nachrichten” w 1790 roku grono profesorów Gimnazjum Gdańskiego dziękowało jednemu z anonimowych ofiarodawców ${ }^{2}$.

Wprawdzie po roku 1660 w Prusach Królewskich — globalnie rzecz biorąc - liczba podejmujących studia spadła, zmniejszeniu uległa ona również w ciągu wieku XVIII, lecz mieszczanie gdańscy przejawiali nadal zainteresowanie wysyłaniem synów na naukę do

\footnotetext{
' Ms 504 BG PAN, k. 272-275, 278-292, 299-306 (M. K. Hanow: Index stipendiorum Gedanensium). Por. też M. Pawlak, Uwagi nad socjotopografia inteligencji gdańskiej w XVI-XVIII wieku, „Zeszyty Naukowe Wydziału Humanistycznego Uniwersytetu Gdańskiego", Pedagogika, Historia Wychowania 1985, s. 51.

2 "Wöchentliche Danziger Anzeigen und dienliche Nachrichten” 1790, nr 31, s. 526; nr 32, s. 541-542. Egz. BG PAN, sygn. X $3518^{\circ}$.
} 
różnych ośrodków akademickich ${ }^{3}$. W pięcioleciu 1701-1705 studia podjęło 57 synów mieszczańskich, w latach 1771-1772 tylko 16, lecz ogółem od 1701 do 1772 studiowało ponad 800 gdańszczan ${ }^{4}$, wśród których byli synowie pastorów, urzędników miejskich (syndyków, podsyndyków, sekretarzy i pisarzy), lekarzy, profesorów i nauczycieli, rajców, kupców i rzemieślników ${ }^{5}$.

Przechodząc od liczb do nazwisk i osób je noszących, przyjrzyjmy się tym, którzy po nauce, po studiach odegrali znaczącą rolę w Gdańsku lub poza jego granicami ${ }^{6}$. Nie o pełny obraz akademickich peregrynacji i późniejszych karier młodych gdańszczan tutaj chodzi; rzecz jedynie w tym, by uświadomić sobie, kto studiował i kim stał się dla miasta po powrocie z zagranicy.

Spośród studiujących w samych początkach XVIII wieku wybierzmy kilku, urodzonych u schyłku poprzedniego stulecia. Jan Arnd (1682-1748) uczył się w Gimnazjum Gdańskim, studiował w Rostocku, gdzie uzyskał magisterium. Po powrocie w strony rodzinne uczyl w gimnazjach Gdańska i Torunia, następnie przeniósł się do Królewca, gdzie został profesorem historii. Zmarł jako rektor szkoły w Tylzy. Pozostały po nim prace historyczne, astronomiczne i metcorologiczne, oparte na obserwacjach. Jan Bogumił Becker (1684-1747) po nauce w Gimnazjum Gdańskim studiował w Halle i w Holandii (do 1712). W mieście rodzinnym był adwokatem, a także lawnikiem i rajcą Starego Miasta. Gotfryd Lengnich (1689-1774), uczeń Gimnazjum Gdańskiego, studiował prawo i historię w Halle, w 1713 roku promowany na doktora. W 1729 roku został w Gimnazjum profesorem wymowy i poezji, kilkanaście lat później prawa i historii, na koniec syndykiem miejskim. Należał do najwybitniejszych postaci Gdańska; zasłużył się jako prawnik i historyk, autor wielu dzieł. Jan Jakub Mascov (1689-1761), uczeń Gimnazjum Gdańskiego, studiował od 1709 roku w Lipsku teologię, prawo i historię. Doktoryzowal się w Halle (1718) w dziedzinie prawa. W Lipsku został profesorem i pełnił jednocześnie wiele innych funkcji publicznych w mieście. Pozostawił po sobie liczne prace historyczne. Jakub Gellentin (1691-1750) studiował medycynę w Królewcu (1709), w Jenie i Halle, gdzie w 1712 roku doczekał się promocji doktorskiej. W Gdańsku był czynny jako lekarz. Na koniec Daniel Fryderyk Hoheisel (1698-1732), który po nauce w Gimnazjum Gdańskim studiował od roku 1717 prawo i filozofię w Lipsku. Uzyskał tu magisterium (1720), a w Halle doktorat prawa (1723). W mieście tym pozostał; pracował jako nauczyciel i zajmował się pracą naukową.

Spośród urodzonych w początkach XVIII wieku wymieńmy trzech; studiowali oni w latach dwudziestych. Jan Fidalke (1703-1763), uczeń Gimnazjum Gdańskiego, studiował

${ }^{3}$ M. Pawlak, Studia uniwersyteckie mtodzieży z Prus Królewskich $w$ XVI-XVIII $w$., Toruń 1988, s. 81-82; tenże, Die Universitätsstudien der Jugend der Städte von Königlich Preußen im XVI-XVIII.Jh., ,Studia Maritima”, t. I (1978), s. $108-112$.

+ M. Pawlak, Studia uniuversyteckie mlodzieży z Prus Króleuskich w XVI-XVIII w., op. cit, tabela 1.

${ }^{5}$ Ibidem, tabela 5.

${ }^{6}$ Wykorzystano tu Altpreußische Biographie, Bd. I Königsberg 1941; Bd. II, Marburg/Lahn 1967; Bd. III, Marburg/Lahn 1975. 
teologię w Rostocku (1723), w Lipsku (1725), gdzie osiągnął stopień magistra. Po powrocie do miasta nad Motławą został w Gimnazjum profesorem greki i języków orientalnych, wreszcie pastorem kościoła Św. Bartłomieja. Jerzy Fryderyk Cosak (1707-1773), uczeń Gimnazjum Gdańskiego, od 1729 roku studiował w Wittenberdze. Był później czynny w Gdańsku i poza nim jako duchowny. Daniel Gralath (1708-1767), uczeń Gimnazjum Gdańskicgo, studiował w Halle i w Marburgu, w 1734 roku wrócił do Gdańska, gdzie był rajcą i burmistrzem, poświęcając się też pracy naukowej.

Kilkanaście lat później studia rozpoczęło kilku kolejnych gdańszczan. Jan Konrad Eichhorn (1718-1790), uczeń Gimnazjum Gdańskicgo, w latach 1741-46 studiował teologię w Jenie. Osiadł w Gdańsku jako duchowny, prowadzący jednocześnie badania przyrodoznawcze. Duchownym został również (między innymi w Wisłoujściu) Beniamin Efraim Krüger (1719-1789), który od 1739 roku studiował w Królewcu, a następnie w Lipsku (od 1743) i w Wittenberdze (od 1745). Beniamin Groddeck (1720-1776) studiował prawo, teologię i filozofię w Lipsku, gdzie się w 1744 roku habilitował. W 1748 roku został profesorem w Gimnazjum Gdańskim. Jan Bentzmann (1727-1795) studia - prawne — odbył w kilku ośrodkach uniwersyteckich, między innymi w Lipsku (1747). Po powrocie do Gdańska został najpierw sekretarzem miasta, następnie burmistrzem.

Do innej już generacji zaliczyć trzeba tych, którzy podjęli studia kilka, ewentualnie kilkanaście lat po 1750 roku. Wilhelm Lau (1730-1807) po ukończeniu Gimnazjum Gdańskiego podjął w 1767 roku studia teologiczne, po czym działał jako duchowny. Efraim Krüger (1734-1789) studiował medycynę w Lipsku, gdzie w 1758 roku uzyskał doktorat. W mieście rodzinnym był lekarzem, pracował również naukowo. Jan Bogumił Bartoldi (1736-1788) nauki pobicrał najpierw w Gimnazjum Gdańskim, w Rostocku studiował teologię i matematykę (1757-61), w Jenie matematykę i prawo (1761-1763). W 1773 został profesorem matematyki w Gimnazjum Gdańskim. Zajmował się między innymi wydawaniem kalendarzy. Daniel Gralath (1739-1809), syn wymienionego już burmistrza, uczył się w Gimnazjum Gdańskim, a studiował w Królewcu, gdzie w 1763 roku uzyskał doktorat prawa. Przez 45 lat (od 1764) był profesorem iuris w Gimnazjum Gdańskim, w latach 1799-1809 był rektorem.

Do tego samego pokolenia należeli ponadto inni. Wymieńmy jeszcze nicktórych z nich. Karol Beniamin Lengnich (1743-1795), bratanek i zięć wspomnianego już syndyka i uczonego gdańskiego, uczeń nadmotławskiego Gimnazjum, studiował w Lipsku. Po powrocie do Gdańska rozpoczął karierę duchowną. Publikował kazania i prace z zakresu historii i numizmatyki. Karol Benedykt Cosak (1746-1797) studiował w Lipsku. Po powrocie nad Motławę był najpierw rektorem szkoły Św. Jana, następnie został profesorem wymowy w Gimnazjum Gdańskim. Henryk Nudow (1752 - ok. 1800) studiował w Lipsku, gdzie uzyskał stopień magistra filozofii, a w 1776 roku wypromowany został na doktora medycyny. Po studiach pracował jako lekarz w Gdańsku, lecz już w 1779 roku opuścił miasto rodzinne i wyjechał do Rosji. Był między innymi profesorem fizjologii, patologii i terapii w St. Petersburgu. Samuel Benedykt Flander (1753-1803) studiował w Lipsku prawo, po czym w 1778 roku wrócił do miasta rodzinnego, gdzie został sędzią, a następnie notariuszem. Filip Adolf Lampe (1754-1827) uczył się w Gimnazjum Gdańskim, studiował medycynę w Getyndze i Stras- 
burgu. Wrócił do Gdańska jako doktor medycyny i rozpoczął tu działalność na stanowisku lekarza miejskiego. Łączył ją z pracą naukową w dziedzinie fizyki i chemii. Został z czasem profesorem matematyki w Gimnazjum Gdańskim, a w 1813 jego rektorem. Natan Berendt (1756-1838) był najpierw uczniem Gimnazjum Gdańskiego, następnie studiował w Getyndze (1771-1780). Doszedł do doktoratu medycyny. Od 1782 roku pracował w Gdańsku jako lekarz. Lekarzem został również Natan Ernest Dauter (1756-1813), uczeń Gimnazjum Gdańskiego, który po studiach w Getyndze jako doktor medycyny osiadł w Gdańsku. I jeszcze dwaj lekarze. Filip Efraim Blech (1757-1812), uczeń Gimnazjum Gdańskiego, studiował w Lipsku, od 1784 roku czynny jako lekarz w Gdańsku. Lewi Józef Hirsch (1758-1823) w 1784 roku rozpoczął studia medyczne w Królewcu, w 1791 doczekał się promocji doktorskiej i pozostał w mieście swoich studiów, pełniąc tam obowiązki lekarskie. Wreszcie ostatni z tej generacji: Karol Fryderyk Teodor Bertling (1754-1836). Uczył się w Gimnazjum Gdańskim, studiował teologię w Lipsku i Getyndze. Od 1782 roku w mieście rodzinnym był czynny jako duchowny. W zaawansowanym wieku — w 1824 roku - został doktorem teologii (w Greifswaldzie).

Przechodzimy do urodzonych w 1760 roku i w kolejnych latach. Bogumił Hufeland (1760-1817) studia - w zakresie filozofii i prawa — podjął w 1780 roku w Lipsku, Kontynuował je w Getyndze i Jenie, gdzie w 1785 roku otrzymał doktorat prawa i filozofii. Tamze został profesorem. Karol Bogumił Doering (1761-1827) po nauce w Gimnazjum Gdańskim studiował prawo w Getyndze (1782) i w Lipsku (1785). Wróciwszy do Gdańska poświęcił się pracy administracyjnej; doszedł do urzędu burmistrza. Ernest Gotfryd Groddeck (1762-1823), syn wspomnianego profesora Gimnazjum Gdańskiego, studiował w Getyndze (1782-1785); w 1804 roku został profesorem języków orientalnych w Wilnie. Jan Gotfryd Kleefeld (1763-1845) po nauce w Gimnazjum Gdańskim studiował medycynę w Jenie. W 1792 osiadł w Gdańsku i był tu czynny jako lekarz. Jerzy Aleksander Lankau (1764-1843) studiował prawo w Getyndze, a po powrocie do miasta rodzinnego pełnił różne funkcje w sądownictwie i administracji. Samuel Bogumił Lange (1767-1823) uczył się w Gimnazjum Gdańskim, studiował w Jenie i został tam w 1796 roku profesorem filozofii, następnie teologii, w późniejszych latach został profesorem teologii w Rostocku, gdzie pozostał do śmierci. Franciszek Krystian Brunatti (1768-1835) od 1790 studiował w Jenie i Würzburgu; działał jako lekarz w Gdańsku i Elblągu. Joachim Henryk Weickhmann (1769-1857), uczeń Gimnazjum Gdańskiego, od 1789 roku studiował prawo w Getyndze, później w Lipsku; po powrocie z zagranicy uczestniczył bardzo aktywnie w życiu publicznym swojego miasta; doszedł do urzędu burmistrza.

Zamykając listę gdańskich peregrynantów, z natury rzeczy niepełną, wymieńmy jeszcze najmłodszego z nich — Bogumiła Salomona (1774-1865), który od 1791 roku studiował w Królewcu medycynę; wypromowany w 1797 roku, podjął praktykę lekarską w Amsterdamie, następnie w Lejdzie. Jego aktywność życiowa i zawodowa przypadła już na wiek XIX.

Studia, jak widać, torowały drogę do kariery. Powracający z zagranicy zostawali kaznodziejami i pastorami, rajcami i burmistrzami, sekretarzami, sędziami i notariuszami, lekarzami i profesorami. Niektórzy realizowali swoje plany życiowe poza murami swego miasta. 
Nic dziwnego, że wyjazd na studia do znanych ośrodków uniwersyteckich był wydarzeniem, i to w życiu nie tylko jednostki, lecz także środowiska, z którego się młody gdańszczanin wywodził. Wydarzeniem tym ważniejszym, że peregrynacja akademicka oznaczała rozstanie nieraz na długie lata, studiowano wówczas bowiem przeważnie do czterech, sześciu lat, rzadziej powyżej ${ }^{7}$, na ogół w jednym lub dwóch uniwersytetach ${ }^{8}$. Można więc powiedzieć, że z miastem rodzinnym, z przyjaciółmi i kolegami rozstawali się wyruszający w świat na czas dłuższy, toteż wyjazdom nadawano uroczystą oprawę. W Gimnazjum Gdańskim ustalił się nawet zwyczaj żegnania przyjaciół i kolegów słowem literackim. Powstałe z tej okazji utwory od początku wieku XVIII zaczęto wydawać w postaci większych lub mniejszych, lecz na ogół skromnych druczków.

\section{Problemy terminologiczne}

Na wspomniane publikacje składały się już to pojedyncze utwory, już to zbiory, nieraz bardzo licznych, tekstów różnych autorów rozmaicie przez nich — w tytułach — nazywanych: Denkmal der Freundschaft ${ }^{9}$, Almanach der Freundschaft ${ }^{10}$, Freudnschaftliche Gedanken und Wïnsche ${ }^{11}$,

7 M. Pawlak, Studia uniwersyteckie młodzieży z Prus Królewskich w XVI-XVIII w., op. cit., tabela 31.

${ }^{8}$ Ibidem, tabela 32.

${ }^{9}$ Denen [...] Herm Heinrich Jacob Martens und Herrn Johann Gottlieb Martens, beyder Rechte rühmlichst Beflissenen, bei Ihrer Abreise nach Göttingen zum Denkmal aufrichtiger Freundschaft geweihet von Innenbenannten. Im September Monathe des 1773 sten Jahres, Danzig [1773]. Egz. BG PAN, sygn. Oe $84532^{\circ}$. — Denen [...] Herren Michael Mylcke, Johann Rohleder und Jacob Friedrich Benthien, der Gottesgelahrtheit rïhmlichst Beflissenen bey Ihrer Abreise nach Königsberg und Greiffswalde zum Denkmal aufrichtiger Freundschaft geweihet von Innenbenannten. Im Monat September des 1773 sten Jahres, Danzig [1773]. Egz. BG PAN, sygn. Oe $87142^{\circ}$. - An den Wohledlen und Wohlgelahrten Herrn Herm Paul Schnaase der Rechte rïhmlichst Beflissenen bei Seiner Abreise nach Göttingen. Zum Denkmal der aufrichtigsten Freundschaft gewidmet von Immenbenannten. Im Ostermonde 1783. Danzig [1783]. Egz. BG PAN, sygn. Oe $608^{\circ}$ adl. 34. - Denkmal der Freundschaft. Unserm theuersten Freunde, Herrn Johann Jacob Schalk, der Gottesgelahrheit rïhmlichst Beflissenen bei Seiner Abreise auf die hohe Schule nach Jena. Im Aprilmonat 1793. Im Namen Innenbenannter errichtet von J. E. Seegers, d. G. G. B., und C[hristian] G[abriel] Schultz, Danzig [1793]. Egz. BG PAN, sygn. Oe $778^{\circ}$ adl. 4.

${ }^{10}$ Almanach der Freundschaft für das Jahr 1796. Bey Walter, Braunschweig, Payne und Erdmann. Unserm allgemein geliebten Freunde, Herm C[arl] F[riedrich] B[enedict] Cosak, d. G. G. B., bei Seiner Abreise im Weinmonat anf die Universität Halle gewidmet von Innenbenannten, Danzig [1795]. Egz. BG PAN, sygn. Oe $778^{\circ}$ adl. 8.

"Freundschaftliche Gedanken und Wïnsche bey der Abreise Hern Johann Carl Friese, der Rechte rïhmlichst Beflissenen nach der Universität zu Königsberg. Gesammelt von J. H. Weickhmann und T. C. Haber, 1787, im September, Danzig [1787]. Egz. BG PAN, sygn. Oe $708^{\circ}$ adl. 6. - Als der (Tit.) Herr Paul Gotthard Mampe der Gottesgelahrtheit Beflissener sein alhier rïhmlichst gefïhrtes Studiren fortzusetzen im Jahr 1741 von Danzig nach Sächsischen hohen Schulen abreisete begleiteten Denselben mit einigen aufrichtigen Wïnshcen innenbenannte Freunde, Danzig [1741]. Egz. BG PAN, sygn. Oe $1712^{\circ}$ adl. 20. - Als die [...] Herren Herr Johann Gottfried Falck und Herr Georg Ernst Remus der Arzeney-Wissenschaft eifrigst Beflissene Ihr bishero rïmlich gefiurtes Studiren fortzusetzen von Danzig nach der hohen Schule zu Göttingen abreiseten begleiteten Dieselbe mit einigen Wïnschen innen benannte Freunde. Danzig, den 23 August 1747 , [Danzig 1747]. Egz. BG PAN, sygn. Oe $1712^{\circ}$ adl. 3. - Als die Wohlädle und Wohlgelahrte Herren, Herr Philip Silvester Lürsenius der Arzeney-Wissenschafft Beflissener nach Leyden und der Wohlgebohme Herr Carl Joachim von Behr der Rechts-Gelehrsamkeit Beflissener nach Rostock zu Fortsetzung ihrer gelehrten Bemiuhungen im Jahr 1748 am 14 ten des Augustmonats von Danzig abreiseten, begleiteten Dieselbe mit folgenden Wïnschen die in diesen Blättern benannte Freunde, Danzig [1748] Egz. BG PAN, sygn. Oe $1712^{\circ}$ adl. 19. - Als die [...] Herren Herr Abraham Wolters und 
Mnemosynon ${ }^{12}$, Abschiedsgedicht ${ }^{13}$, Quodlibet ${ }^{14}$. W tytułach dominował - jak widać - motyw przyjaźni; stanowił on bodaj najważniejszy elemetn genezy i struktury interesujących nas tutaj przedsięwzięć edytorskich. Natomiast tytuł zbiorku Mnemosynon kojarzy się z gr. mneme (= pamięć), z Memosyne, z boginią pamięci, matką muz, a także z popularnym niegdyś wierszem mnemotechnicznym, którego rytm i rym służyły lepszemu zapamiętywaniu rozmaitych formuł, reguł gramatycznych, nazwisk. Innymi słowy - eksponował drugi, równie istotny jak poprzedni, motyw: pamięć. Z kolei Abschiedsgedicht i pojawiający się często w tytułach rzeczownik Abschied przypominał zarówno okoliczności, które powołały utwór do życia: pożegnanie, rozstanie, jak i związaną z tą sytuacją strukturę literacką, jaką była pieśń pożegnalna, obecna w literaturze od starożytności pod nazwą propemptikonu.

Quodlibet. Mianem tym obejmowano w średniowieczu dysputy filozoficzne i teologiczne na różne tematy, a także utwory muzyczne łączące w sobie rozmaite melodie i teksty słowne. Dodać należy, że w muzyce wyróżniano quodlibet monofoniczny i polifoniczny. Pierwszy opierał się na występowaniu melodii kolejno po sobie, a więc w sposób sukcesywny, drugi zaś — polifoniczny — na prowadzeniu wielu melodii o różnym rodowodzie w kilku głosach kompozycji, w sposób symultaniczny. Quodlibet jako komponent tytułu zbiorków, o których tutaj mówimy, zwracał uwagę właśnie na różnorodność zawartości, na obecność tekstów wierszowanych i prozaicznych, cytatów i obiegowych sentencji.

Warto w tym miejscu raz jeszcze przypomnieć, że w pierwszym ukazującym się w Gdańsku czasopiśmie moralnym — „Die mühsame Bemerckerin derer Menschlichen Handlun-

Herr Johann Heinrich Martens, Beyder Rechten und der schönen Wissenschaften bisher eifrigst Beflissene zu Fortsetzung Ihrer gelehrten Bemühungen von hier nach Göttingen abreiseten begleiteten Selbige mit aufrichtigen Wiunschen innen benannte Freunde. Danzig, den 11 April 1752, [Danzig 1752]. Egz. BG PAN, sygn. Oe $552^{\circ}$ adl. 82. Freundschaftliche Wïnsche an Herm Johann Benjamin Schmidt, der Rechte und schönen Wissenschaften eifrigst Beflissenen bey Seiner Abreise auf die hohe Schule zu Leiden von Innengenannten. Danzig, 1758 im April-Mond, [Danzig 1758]. Egz. BG PAN, sygn. Oe $642^{\circ}$ adl. 105.

12 [Johann Christian Boguslaus] v[on] W[obeser], Mnemosynon. Dem Herrn August Friedrich Joseph Bogislav Kuhn, b[eide] R[echte] B [eflissener] bey seiner Abreise auf die hohe Schule zu Königsberg von Hintenbenannten gewidmet, Danzig 1797. Egz. BG PAN, sygn. Oe $778^{\circ}$ adl. 10.

${ }_{13}$ Abschiedsgedicht dem Hochedlen und Wohlgelahrten Hern Gabriel Joachim Weickhmann vornehmen Patricius aus Danzig bey Seiner Abreise aus Wittenberg geuidmet von einigen aufrichtigen Freunden [...] den 15 Januar 1759, Wittenberg [1759]. Egz. BG PAN, sygn. Oe $608^{\circ}$ adl. 46. - Als die Herren [...] Herr Joh. Christoph Jänichen, Herr Johann Daniel Reimann, Herr Johann Jacob Haselau, Herr Daniel Gottfried Hündeberg, der Gottesgelahrtheit, und Herr Daniel Aegidius Unselt, der Rechtsgelahrtheit eifrigst Beflissene, zur Fortsetzung Ihrer hieselbst mit vielen Beyfall angefangenen gelehrten Bemïhungen nach hohen Schwlen abreiseten, wollten sich dem immerwährenden Andenken dieser so zärtlich geliebten Freunde durch diese Abschiedszeilen empfelen Innenbenannte, Danzig [1756]. Egz. BG PAN, sygn. Oe $642^{\circ}$ adl. 36. - An den [...] Hern Bernhard Alm der Rechtsgelahrtheit Beflissenen, bey Dessen Abschiede von dem Gymnasio in Danzig zum Zeugniß ihrer Freundschaft von Untengenannten. Im Jahr 1758, den 3ten Aprill, Danzig [1758]. Egz. BG PAN, sygn. Oe $642^{\circ}$ adl. 103.

it Quodlibet für unste geliebte scheidende Freunde, die Wohledle und Wohlgelahrte Herren, Herrn Abraham Friedrich Blech, der Gottesgelahrtheit rühmlichst Beflissenen; und Herm Christian Gottlieb von Schröder, der Rechte rühmlichst Beflissenen, bei Ihrer Abreise nach Göttingen. Im Lenzmonde 1782, Danzig [1782]. Egz. BG PAN, sygn. Oe 59 $8^{\circ}$ ad]. 11; Oe $26528^{\circ}$. 
gen" - znajduje się bardzo krytyczna ocena tej formy wypowiedzi, którą już w początkach XVIII stulecia nazywano właśnic quodlibet:

Vor einigen Jahren war der Quotlibets-Periode Mode. Eine Art von Gedichten, in welchen lustige Einfälle und Gedancken auf eine unordentliche Art zusammen gesetzt sind, und also unnatürlich. Es wurde ein Paar getrauet, man machte ein Quotlibet. Brachte man einen Todten zu seiner Grufft, ein Quotlibet sang ihn zu Grabe. Kam jemand zu Ehren, ein Quotlibet preiste seine Verdienste. Kurtz! alle Dichter wurden Meister-Sänger und Quotlibets-Macher ${ }^{15}$.

W późniejszych latach, a dotyczy to również czasów, kiedy gdańscy uczniowie i studenci publikowali swoje pożegnalne utwory, termin ten występował już bez pejoratywnych obciążen. Wprawdzie przyjaciel Jana Michała Fryderyka Mundta, Pollnau, swój zapis w walecie, pochodzącej z 1784 roku, zaczął od skargi:

Liebster Mundt, es kommen jetzt der Quodlibete so viele, $\mathrm{da}$ ich wahrhaftig zuletzt nicht weiß, was ich darin sagen soll.

lecz nie było to równoznaczne z dyskwalifikacją tej formy przekazu.

W zbiorku dedykowanym Janowi Beniaminowi Schmidtowi, pochodzącym z 1758 ro$\mathrm{ku}^{16}$ Michał Waszkowitz, w roku 1752 wpisany w poczet uczniów Gimnazjum Gdańskiego ${ }^{17}$, posłużył się jeszcze innym terminem: drukowany sztambuch. Czytamy:

Es ist gewiß schwer etwas neues, etwas unerwartetes in ein so genanntes gedrucktes Stammbuch zu setzen. Soll ich über Ihre Abreise klagen? das ist nicht mehr Mode. Soll ich mir Ihre fernere Freundschaft und Wohlgewogenheit ausbitten? Wenn ich auch dieses thäte, so würde es doch vielen als etwas überflüßiges, oder wol gar als etwas prahlerisches scheinen. Es sind gewisse Leute, welche dreust genug sind es als eine lächerliche Sache anzugeben, wenn man in so einem gedruckten Stammbuch aufrichtige und ergebene Freunde Dutzendweise zählen kan, da man doch weiß, daß ein Freund im eigentlichsten Verstande, so eine rare Sache sey. Sie seufzen über den Misbrauch des heiligen Namen der Freunschaft.

15 „Die mühsame Bemerckerin derer Menschlichen Handlungen”. Siebenzehendes Stück. Mittwoch, den 7. Mart. 1736, k. R2r-R2v. Egz. BG PAN, sygn. Dc $22608^{\circ}$. Por. też J. Kasprzyk, Gdańskie czasopiśmiennictuo naukowe i moralne pienuszej poloury XVIII wieku, „Rocznik Gdański”, t. XXVII, 1968, s. 62.

${ }^{16}$ Freundschaftliche Wünsche an Herrn Joharm Bejamin Schmidt, der Rechte und schönen Wissenschaften eifrigst Beflissenen bey Seiner Abreise auf die hohe Schule zu Leiden von Innengenannten. Danzig, 1758 im April-Mond, [Danzig 1758]. Egz. BG PAN, sygn. Oe $642^{\circ}$ adl. 105.

${ }^{17}$ Księga wpisów uczniów Gimnazjum Gdańskiego 1580-1814, opr. Z. Nowak, P. Szafran, Poznań 1974, s. 339. 
I przytoczony fragment, i dalsze partie wywodów — tutaj nie cytowane — są interesujące nie tylko ze względu na występujący w nich termin, lecz także z uwagi na rozważania dotyczące zawartości owych drukowanych sztambuchów. Czy należy w nich — zastanawia się autor — skarżyć się na rozstanie z przyjaciólmi wyruszającymi w podróż, pisać o przyjaźni, skoro tak wiele słów jej poświęcono, i to w momencie, kiedy przyjaźn wydaje na ogół ostatnie tchnienie („den letzten Athem holet”). Czy należy pisać o charakterze wyjeżdżającego? O jego zamiarach kontynuowania nauki? W przekonaniu autora wypada po prostu się pożegnać i złożyć życzenia. Dopowiedzmy: te dwa motywy - pożegnania i życzenia — istotnie zadomowiły się w drukowanych sztambuchach, by pozostać przy określeniu Waszkowitza.

Świadomość związków między drukowanymi sztambuchami a właściwymi czyli rękopiśmiennymi imionnikami musiała być wśród autorów i wydawców silna, skoro niektórzy $\mathrm{z}$ nich $\mathrm{w}$ publikowanych przez siebie zbiorkach korzystali chętnie z druku naśladującego rękopis, dokładniej mówiąc: wpis w imionniku dokonany ręką. Takjest na przykład w tomiku dedykowanym Konstantemu Ernestowi Groddeckowi i Janowi Wilhelmowi Johnowi ${ }^{18}$.

Wróćmy do terminów. Nie ma przeszkód, by śladem osiemnastowiecznych autorów na oznaczenie interesujących nas tutaj druczków posługiwać się przynajmniej dwoma spośród obecnych w tytułach i w wpisie Waszkowitza. Chodzi tu o: quodlibet i drukowany sztambuch.

Pierwszy z nich przyjmujemy, ponieważ spełnia kryterium kongruencji, zgodności nazwy i zawartości tomików przynoszących, jakjuż wspomniano, bardzo różne teksty, związane między innymi z wyjazdem bliskiej osoby, i — co nie jest bez znaczenia - upowszechnił się w XVIII wieku. Można się nawet pokusić o wprowadzenie do obiegu — oczywiście tylko na zasadzie przenośni - rozróżnienia znanego historykom muzyki: quodlibet monofoniczny i quodlibet polifoniczny. Pisząc tutaj (tj. w kontekście określonych realizacji edytorskich): quodlibet monofoniczny mieć będziemy na uwadze druczki zawierające jeden tylko utwór, pisząc zaś: quodlibet polifoniczny myśleć będziemy o tomikach złożonych z tekstów różnych autorów, tworzących swoiste antologie czy — lepiej — imionniki.

Drugi z wymienionych terminów: drukowany sztambuch zasługuje również na uwzględnienie, znaczna bowiem część interesujących nas tutaj zbiorków przypomina sztambuchy czy — inaczej — imionniki. Od początku były one traktowane jako księgi przyjaźni, jako pomniki przyjaźni. Nazywano je album amicorum, przy czym słowo album kojarzono z bielą karty, wręczanej przyjacielowi, koledze, by obdarowany mógł ją wcielić do swego zbioru, do sztambuchu, imionnika. Inne nazwy - philotheca, liber memoralis, thesaurus amicorum, libellus amicorum, liber amicorum, theatrum eruditorum - świadczą również, iż imionnik zostal pomyślany jako księga przyjaźni i pamięci, wskazują nadto na jego walory erudycyjne, pośrednio także na fakt, że był on w obiegu wśród uczniów, studentów i ich uczonych

${ }_{18}$ An die [...] Herrn Constantin Ernst Groddeck und Herrn Johann Wilhelm John, als Sie um Ihre Bemühungen in der Rechtsgelahrtheit und Arzney-Wissenschaft weiter zu bringen, am 24sten May des 1757sten Jahres nach Leiden abgiengen, zum Zeugniß ihrer Freundschaft von Innengenannten, Danzig [1757]. Egz. BG PAN, sygn. Oe $642^{\circ}$ adl. 75. 
mistrzów ${ }^{19}$. Zbieżności między imionnikiem a imionnikiem drukowanym niewątpliwe! Nie można wszelako zapominać o różnicach. Imionnik byt zawdzięczał inicjatywie swego właściciela i pozostawał w jego rękach, z jego też przeważnie inspiracji przybywało w nim wpisów. Natomist drukowany imionnik był dziełem przede wszystkim tych, którzy postanowili ofiarować go swoim przyjaciołom i kolegom, a więc autorów i inspiratorów opublikowania; powstawał nadto, o czym nie należy zapominać, przy udziale typografów. Imionnik zachowywał od początku do końca postać rękopiśmiennej księgi czy — raczej — książeczki, siłą rzeczy pozostawał w jednym egzemplarzu, był niepowtarzalny. Natomiast drukowany sztambuch był powielany, i to w sposób mechaniczny, dzięki czemu można było dojść do określonej liczby egzemplarzy. Wysokość nakładu zależała od woli autorów, dedykujących imionnik przyjacielowi lub koledze, niekiedy dwom, trzem przyjaciołom i kolegom. Pamiętając o tym wszystkim, terminem drukowany sztambuch, drukowany imionnik — niekiedy nawet z pominięciem epitetu „drukowany” - będziemy się posługiwali wcale często. Skorzystamy również z ich grecko-łacińskich odpowiedników: philotheca, liber memoralis, thesaurus amicorum, libellus amicorum, luber amicorum, theatrum eruditorum.

Do wymienionych już terminów - quodlibet i drukowany imionnik (sztambuch) dodajmy jeszcze jeden: waleta. Termin ten — od łac. vale (bywaj zdrów, żegnaj), valedico (żegnam się z kimś) - nie był autorom gdańskim znany, nie doczekał się też nigdy teoretycznej kodyfikacji. Nie można wszakże przeoczyć faktu, że w programie nauczania na rok 1724 profesor wymowy i poezji Gimnazjum Gdańskiego, Jan Sartorius, wyliczył między innymi takie formy literackiej wypowiedzi, jak eucharistica, consolatoria, gratulatoria i salutatoria $^{20}$, w roku zaś 1727 dodał do już wymienionych valedictoria ${ }^{21}$. Miał przy tym na uwadze wiersze (także utwory prozaiczne) dziękczynne, pocieszające, winszujące, witające $\mathrm{i}$ - to nas w tym miejscu interesuje — żegnające.

Tutaj nazwą waleta obejmować będziemy utwór (a może nim być kantata, propemptikon, list) lub zespół różnych tekstów (z cytatami, maksymami, epigramami, różnymi odmianami pieśni, listami) napisanych z myślą o wyjeżdżających na studia i do nich adresowanych ${ }^{22}$, mających odpowiedni kształt edytorski.

\footnotetext{
${ }^{19}$ Por. E. Kotarski, O imionnikach XVI i XVII wieku, [w:] Staropolska kultura rękopisu, pod red. H. Dziechcińskiej, Warszawa 1990, s. 93-111.

${ }^{20}$ Por. I. N. I. Catalogus lectionum et operarum publicarum in Athenaeo Gedanensi hoc cursu annus expediendarum, propositus Januario ineunte, 1724, Gedani [1724]. Egz. BG PAN, sygn. Ma $39248^{\circ}$ adl. 60.

${ }_{21}^{2}$ I. N. I. Catalogus lectionum et operarum publicarum in Athenaeo Gedanensi hoc cursu annus expediendarum, propositus Januario ineunte, 1727, Gedani [1727]. Egz. BG PAN, sygn. Ma $39248^{\circ}$ adl. 63.

${ }_{22}$ W innym znaczeniu nazwa ta występuje u S. Nieznanowskiego (Waleta, [w:] Slownik literatury staropolskiej, pod red. T. Michałowskiej przy udziale B. Otwinowskiej, E. Sarnowskiej-Temeriusz, Wrocław 1990, s. $885-887)$.
} 


\section{Quodlibet monofoniczny. Kantaty — propemptika - listy}

Przyjrzyjmy się najpierw publikacjom należącym do pierwszcj kategorii, na które — jak wspomniano - składały się pojedyncze utwory. Innymi słowy: w polu naszego widzenia znajdzie się quodlibet monofoniczny. Oto w roku 1701 Jan Leonard Schlicher, gdańszczanin, uczeń Gimnazjum Gdańskiego (od 1700 roku $^{23}$ ), wierszowaną waletą żegnał swego starszego przyjaciela, Jana Jerzego Rosenberga, rozstającego się z Gimnazjum Gdańskim ${ }^{24}$ po odbyciu dysputy $^{25}$. Inny autor, Jerzy Schwertzlaff, będący także uczniem tej uczelni (od $1705 \mathrm{roku}^{26}$ ), opublikował w roku 1706 serenadę czy „śpiew” (Sing-Gedicht) 27 poświęcony dwom przyjaciołom - Rajnoldowi Rudolfowi Behnemu i Janowi Wilhelmowi Hagdornowi ${ }^{28}$. W tym samym roku z podobnym utworem wystąpił anonim (może był nim Schwertzlaff?), który swój utwór określił również mianem Sing-Gedicht ${ }^{29}$. Napisał go z myślą o studencie teologii i filozofii, Karolu Gotfrydzie Heiniusie, gdy ten zdecydował się — po publicznym wygłoszeniu mowy w dniu 11 listopada 1706 roku - kontynuować naukę w Rostocku. I jeszcze jeden przykład - tym razem z końca wieku — autorstwa Karola Beniamina Feyerabenda ${ }^{30}$, ucznia Gimnazjum Gdańskiego od 1781 roku $^{31}$. Adresatem tego tekstu był Franciszek Brunatty (Brunatti). Znamy również autora Mnemosynonu. Pod tekstem znajdujemy wprawdzie tylko inicjał: v. W., lecz rozwiązanie przynosi lista ofiarodawców, na której znajdujemy — wśród niemal trzydziestu innych - nazwisko von Wobesera. Nosił je Jan Krystian Bogusław Wobeser $^{32}$, który od 1795 roku był uczniem Gimnazjum Gdańskiego ${ }^{33}$.

${ }^{23}$ Ksiega upisóu', op. cit., s. 273.

${ }_{24}$ Joh [ann] Leonhard Schlicher, Kennbahres Zeichen Treugepflogener Freundschaff, welches als der Edle und Gelahrte Herr Joh. George Rosenberg, der Rechten euffrigst Beflissener nach gehaltener Disputation, von dem löblichen Athenaeo in Dantzig den 15. Sept. 1701 Seinen Abschied nahm, hat darstellen wollen dessen Auffichtiger..., Dantzig [1701]. Egz. BG PAN, sygn. Oe $108^{\circ}$ adl. 54.

${ }^{25}$ Pod opieką profesora Samuela Fryderyka Willenberga (1663-1748), prawnika. Por. J. G. Rosenberg, De iure principi negato circa territorium summ, Gedani 1701. Egz. BG PAN, sygn. Od 17347/6 $8^{\circ}$ adl. 3.

${ }^{26}$ Ksiega upisów, op. cit., s. 281.

${ }^{27}$ Georg Schwertzlaff, Der bekrönete Tugend-Fleiß bey Abreisen der Edlen und Wohlgelahrten Herren Hn. Reinhold Rudolph Behnen und Hn. Johann Wilhelm Hagdorn, Gedanens. et L. L. Stud. da sie vorhero mit öffentlichen Sermonen, als De Insignibus Prussiae und De Dantisco, ab excusso Cruciferorum dominatu rebus dubiis servata, in Auditorio Athenaei Maximo Anno 1706, den 18. Novembr. valedicinten in einer kunzen Serenat, oder Sing-Gedichte vorgestellet von Dero dienstergebensten Freunde..., Danzig [1706]. Egz. BG PAN, sygn. Oe $108^{\circ}$ adl. 136; Oe $342^{\circ}$ adl. 25.

${ }_{28}$ Por. jego dysertację napisaną pod opieką profesora Samuela Fryderyka Willenberga De arbitris et mediatoribus belligerantium, Gedani [1706]. Gez. BG PAN, sygn. Od $173514^{\circ}$ adl. 2.

${ }^{29}$ Die siegende Besckickligkeit im Reisen wurde bey der Abreise des [...] Herrn Carl Gottfried Heinii. S. S. Theol. et Philos. Stud., da Er zuvor den 11. Novembr. A. 1706 in einer üffentlichen Sermon De devotis Patriae sich zugleich dem Vaterlande verpflichtet in einem kuntzen Sing-Gedichte aus Trieb einer treugepflogenen Freundschafft von einem ergebensten Freunde vorgestellet, der anf eine ruhmuvïrdige Reise beständig dencket, Dantzig [1706]. Egz. BG PAN, sygn. Oe $138^{\circ}$ adl. 15.

${ }^{30}$ Carl Benjamin Feyerabend, Meinem vielgeliebten Freunde Franz Brunatty bey seiner Abreise nach Jena mit herzlicher Brudertreue gewidmet von [...]. Im September 1790, Danzig [1790]. Egz. BG PAN, sygn. Oe $778^{\circ}$ adl. 2.

${ }^{31}$ Ksiegga wpisóu', op. cit., s. 364.

32 Por. przyp. 12.

33 Ibidem, s. 374. 
We wszystkich wyliczonych tu wypadkach w grę wchodziło autorstwo jednostkowe: przyjaciel kierował do przyjaciela lub przyjaciół napisany przez siebie utwór. Był on przy tym -- mogliśmy się o tym przekonać - zawsze uczniem Gimnazjum Gdańskiego. Z tego samego środowiska wywodzili się też adresaci tekstów. Schlicher swój wiersz dedykował Janowi Jerzemu Rosenbergowi, uczniowi tej uczelni od $1697 \mathrm{roku}^{34}$. Rajnold Rudolf Behne i Jan Wilhelm Hagdorn, do których Schwertzlaff wiersz swój skierował, byli uczniami Gimnazjum Gdańskiego — pierwszy — od 1700 roku $^{35}$, drugi od $1704^{36}$. Karol Gotfryd Heinius został nim w 1699 roku $^{37}$, a Franciszek Krystian Brunatty w roku $1784^{38}$. Odbiorcą Mnemosynonu pióra Wobesera był August Fryderyk Józef Bogusław Kuhnn ${ }^{39}$, uczeń zapisany w metryce gimnazjalnej w 1795 roku $^{40}$. Nie ulega zatem wątpliwości: nie tylko nadawcy, ale i adresaci tekstów związani byli z gdańską uczelnią. To jeden wniosek. Drugi: wszyscy żegnający $-z$ reguły skromniutkimi, dwu-, trzykartkowymi druczkami — przyjaciół i kolegów, opuszczających miasto nad Motławą, występowali jednocześnie w roli autorów tekstów składających się na te publikacje. Przyjmujemy to założenie, nic bowiem nie upoważnia do odrzucenia znaku równania między żegnającym a autorem. Dodajmy: autorów $-z$ jednym ewentualnie (ewentualnie, bo w grę wchodzić może Schwertzlaff) wyjątkiem — znamy $\mathrm{z}$ imienia i nazwiska.

Spotkać się wszelako możemy z praktyką odmienną: nieujawniania (lub: nieujawniania się) autora. $\mathrm{Z}$ połowy wieku pochodzi dwukartkowy druczek ${ }^{41}$ dedykowany Janowi Krzysztofowi Heimowi (przed laty — dokładnie w roku 1730 — zapisanemu w metryce gimna$z_{\text {zjalnej }}^{42}$ ), udającemu się w roku 1748 do Królewca na studia. Na karcie tytułowej figuruje nieco ponad czterdzieści nazwisk ofiarodawców, podpisujących się pod dedykacją, przeważnie gdańszczan (obok których znajdujemy chojniczanina, torunianina, elblążanina). Który $z$ nich był autorem? Nie sposób na to pytanie odpowiedzieć. Identycznie prezentuje się nieco późniejszy, również dwukartkowy, druczek dedykowany Janowi Gotfrydowi Barendtowi, wyjeżdżającemu - po nauce podjętej w Gimnazjum Gdańskim w 1744 roku $^{43}$ — na studia do Jeny w 1749 roku $^{44}$.

\footnotetext{
${ }^{34}$ Ibidem, s. 269.

${ }^{35}$ Ibidem, s. 273.

${ }^{36}$ Ibidem, s. 280.

${ }^{37}$ Ibidem, s. 272.

${ }^{38}$ Ibidem, s. 366.

${ }^{39}$ Por. przyp. 12.

${ }^{40}$ Ksiega wpisów, op. cit., s. 374.

${ }^{41}$ Den [...] Herrn Johann Christoph Heim, der Rechtsgelehrsamkeit und Mathematik eifrigst Beflissenen, als Derselbe im Jahr 1748 am 27sten des Herbstmonats von Danzig nach Königsberg zu Fortsetzung Seiner gelehrten Bemühungen abreisete, begleiteten mit diesem Gedichte folgende Freunde..., Danzig [1748]. Egz. BG PAN, sygn. Qb $100884^{\circ}$ adl. 8.

${ }^{42}$ Ksiega wpisów, op. cit., s. 315.

${ }^{43}$ Ibidem, s. 331.

${ }^{44}$ Als der [...] Herr Johann Gottfried Barendt, der Arzeney-Wissenschaft eifrigst Beflissener im Jahr 1749 den 9 ten des April Monats von Danzig nach Jena zu Fortsetzung Seiner gelehrten Bemühungen abreisete begleiteten Denselben mit diesem Gedichte folgende Freunde.., Danzig [1749]. Egz. BG PAN, sygn. Qb $100884^{\circ}$ adl. 9.
} 
Zwyczaj nieujawniania autora przy jednoczesnym podaniu nazwisk kilku czy kilkudziesięciu ofiarodawców utrwalił się nad Motławą w połowie wieku i utrzymał się po jego kres. Na dowód powołajmy się na tekst dedykowany Karolowi Fryderykowi von Schmelingowi ${ }^{45}$, uczniowi Gimnazjum od 1752 roku $^{46}$, na którego cześć opublikowano zresztą w tym samym roku jeszcze jeden tomik pióra licznej grupy gdańskich autorów ${ }^{47}$. Godna uwagi — w każdym razie $z$ tego punktu widzenia — jest również oda pożegnalna dedykowana Janowi Karolowi Davidsonowi, Janowi Natanowi Schultzowi i Krystianowi Bogumiłowi Sartoriusowi, udającym się w roku 1756 na studia do Lipska ${ }^{48}$. I w tym wypadku pominięto nazwisko autora, natomiast po tekście dedykacji i ody umieszczono trzydzieści nazwisk przyjaciół i kolegów, wśród których z pewnością znajdował się autor. Identycznie lub podobnie pomyślanymi publikacjami żegnano Piotra Wilhelma Biehla (Biela) i Samucla Wilhelma Turnera ${ }^{49}$, uczniów Gimnazjum ${ }^{50}$, Daniela Ehregotta Hanscha, Daniela Ernesta Wagnera i Jana Piotra Ernesta Schefflera ${ }^{51}$, również uczniów ${ }^{52}$, Natana Fryderyka Froma, Walentego Bogusława Hackera i Jana Bogumiła Dragheima ${ }^{53}$, także należących do grona uczniowskiego ${ }^{54}$, Karola Fryderyka Benedykta Cosaka, zapisanego w metryce Gimnazjum w 1791 roku ${ }^{55}$.

Nic można pominąć — w tym kontekścic — innej praktyki. Oto druczek z roku 1797 _ dedykowany innemu uczniowi Gimnazjum ${ }^{56}$, Arturowi Paynemu, z okazji podjęcia przezeń

${ }^{45}$ Ihrem verehrungswiirdigstem Freunde dem [...] Herrn Carl Friedrich von Schmeling, Beyder Rechten, Weltweisheit und Mathematischen Wissenschaften eifrigst Beflißnen widmeten bey seiner Abreise aus Danzig nach Königsberg zum Zeichen aufrichtiger Freundschaft folgende Zeilen unten benannte Freunde.., Danzig [1756]. Egz. BG PAN, sygn. Oe $642^{\circ}$ adl. 2. th Ksiega wpisów" op. cit., s. 339.

${ }^{47}$ Die Abreise des [...] Herrn Carl Friedrich von Schmeling, welche Derselbe zur Fortsetzung Seiner mit Ruhm angefangenen Bemühnngen in der Rechtsgelahrtheit und Weltweisheit im Winter-Monat des 1756sten Jahres nach Königsberg antrat, beklagten in folgenden Zeilen nachstehende Freunde, Danzig [1756]. Egz. BG PAN, sygn. Oe 64 $2^{\circ}$ adl. 1.

${ }^{48}$ Abschieds-Ode denen [...] Herren Herrn Johann Carl Davidson, der Gottesgelahrtheit Beflissenen, Herm Johann Nathanael Schultz, Beyder Rechte Beflissenen, und Herrn Christian Gottlieb Sartorius, Beyder Rechte Beflissenen, bey Ihrer Abreise im Wonnemonat 1756 aus Danzig nach Leipzig zum Zeichen ihrer unveränderlichen Freundschaft gewidmet vor nachstehenden Freunden, Danzig [1756]. Egz. BG PAN, sygn. Oe $642^{\circ}$ adl. 29.

19) Gedicht dem Andenken der Herren Peter Wilhelm Biehl und Samuel Wilhelm Tiurner, der Gottesgelartheit rühmlichst Beflissenen bey Ihrer Abreise nach Jena und Halle gewidmet von Hintenbenannten, Danzig 1761. Egz. BG PAN, sygn. Oe $552^{\circ}$ adl. 3 .

${ }^{50}$ Ksiega upisów, op. cit., s. 340 i 345.

${ }^{51}$ Bei der Abreise der Herren Daniel Ehregott Hansch der Gottesgelartheit Daniel Ernst Wagner der Rechtsgelartheit und Johann Peter Ernst Scheffler der Arzneigelartheit rïhmlichst Beflissenen, nach Jena und Königsberg, wurden folgende Zeilen zum Zeichen ihrer aufrichtigen Freundschaft gewidmet von Hintengenannten. Im Aprilmonat des Jahrs 1760, Danzig [1760]. Egz. BG PAN, sygn. Oe $552^{\circ}$ adl. 38.

${ }^{52}$ Ksiega upisów, op. cit., s. 336, 339, 344.

${ }_{53}$ Ihren Verehrungswürdigen Freunden Herrn Nathanael Friedrich From aus Marienburg, Herm Valentin Lobegott Hacker aus Danzig und Herrn Johann Gottlieb Dragheim aus Danzig, der Gottesgelahrtheit rïhmlichst Beflissenen sind diese Zeilen bey Ihrer Abreise nach Rostock von Untengenannten gewidmet. Danzig im Maymonat des Jahrs 1760, [Danzig 1760]. Egz. BG PAN, sygn. Oe $598^{\circ}$ adl. 36.

${ }^{54}$ Ksiega upisów, op. cit., s. 342, 343, 345.

55 Ibidem, s. 371.

${ }^{56}$ Ibidem, s. 372. 
studiów w Halle ${ }^{57}$. Na karcie tytułowej czytamy między innymi: "gewidmet von Seinen Freunden", daremnie jednak szukamy nazwisk autora i ofiarodawców.

Konkluzja po tym przeglądzie byłaby następująca: W tej grupie walet dominuje anonimowość, z nazwiska bowiem znamy zaledwie kilku autorów. Natomiast nazwiska adresatów dedykacji nie są nam obce; odnajdujemy je — bez wyjątku - w metryce Gimnazjum Gdańskiego.

Waletami obdarowywano uczniów Gimnazjum udających się na studia. Czy jednak wyłącznie ich? Na to pytanie wypadnie udzielić negatywnej odpowiedzi. Przemawia za tym choćby tekst Jana Piotra Knoblocha ${ }^{58}$, dedykowany przyjacielowi wybierającemu się na studia do Rzymu. Autor nie figuruje w metryce gimnazjalnej, a przyjaciela w niej nie szukamy, nie dysponujemy bowiem żadnymi danymi o nim. Na jakiej więc podstawie mielibyśmy łączyć tę waletę z Gimnazjum Gdańskim? Adresaci innego tekstu pożegnalnego 59: Samuel Schmidt, Fryderyk Schwenkner, Daniel Bogumił Bechel i Karol Baltazar Nothwanger są metryce również nie znani, natomiast znajdujemy w niej niektóre, zresztą nieliczne ${ }^{60}$, nazwiska osób umieszczone pod utworem pożegnalnym, a więc wśród ofiarodawców, może autorów. I ten druczek sytuuje się w gruncie rzeczy poza Gimnazjum.

Odrębne miejsce zajmuje wiersz dedykowany przez uczniów Marcinowi Bogumiłowi Pauliemu, profesorowi prawa i historii oraz inspektorowi w Gimnazjum Gdańskim (1753-1763), który opuszczał miasto nad Motławą, by objąć katedrę w Wittenberdze ${ }^{61}$. Tekst ten należy — rzecz jasna - do środowiska gimnazjalnego, tyle tylko, że jego adresatem jest tym razem nie uczeń, lecz profesor.

Podane tu pod koniec przykłady nie zmieniają w sposób istotny obrazu całości: omawiane walety były dziełem przede wszystkim uczniów czy studentów Gimnazjum Gdańskiego. $Z$ ich grona wywodzili się autorzy, inspiratorzy i ofiarodawcy, wreszcie adresaci. Odstępstwa od tej reguły były nieliczne.

Zwyczaj żegnania przyjaciół i kolegów tekstem literackim kultywowali gdańszczanie także poza murami swego miasta. Mógł się o tym przekonać Krzysztof Jan Tannenberg, niegdyś uczeń Gimnazjum Gdańskiego (od 1732 roku $^{62}$ ), gdy po odbyciu studiów w Jenie

${ }^{57}$ Dem Herrn Arthur Payne, d. G. G. B., bey Seiner Abreise auf die Universität Halle gewidmet von Seinen Freunden. Im April 1797, Danzig [1797]. Egz. BG. PAN, sygn. Oe $778^{\circ}$ adl. 12.

${ }^{58}$ Johann Peter Knoblauch, C. atque L. A. in G. A. S., Zum Denkmal der Freundschaft widmete dieses bei der Abreise auf die hohe Schule nach Rom seinen innigst geliebten Freunden [...]. Im Jahr 1795 im Monath September, Danzig [1795]. Egz. BG PAN, sygn. Oe $778^{\circ}$ adl. 6.

${ }_{59}$ Denen [...] Herren Samuel Schmidt, Beyder Rechte Beflissenem, Friedrich Schwenkner, der Gottes Gelahrtheit Befliessenem, Daniel Gottlieb Bechel, der Gottes Gelahrtheit Befliessenem, Carl Balthaser Nothwanger, der Gottes Gelahrtheit Befliessenem, bey Ihrer Abreise nach Wittenberg und Halle von untenbenandten Frennden. Im Jahr 1765 im Monat Aprill, Danzig [1765]. Egz. BG PAN, sygn. Oe $552^{\circ}$ adl.61.

${ }^{60}$ Wymieńmy przykładowo Karola Fryderyka Günthera, Jana Hieronima Riebego i Bogumiła Wernsdorfa.

${ }^{61}$ Als der [...] Herr Martin Gottlieb Pauli, Beyder Rechte Doctor und ordentlicher Lehrer der Rechte und der Geschichte, wie auch Inspector unsers hiesigen akademischen Gymnasiums im Augustmonat des 1763 sten Jahres von Danzig seine Reise auf die hohe Schule nach Wittenberg, den offentlichen Lehrstul zu besteigen, antrat widmeten diese Zeilen zum Zeichen der Hochachtung und Ehrfurcht sämmtliche allhier Studirende, Danzig [1763]. Egz. BG PAN, sygn. Od $173892^{\circ}$ adl. 91. ${ }^{62}$ Ksiega upisów', op. cit., s. 318. 
wracał w ojczyste strony. Otrzymał wówczas w darze pieśń wydaną w Jenie w formie dwukartkowego druku $^{63}$, dedykowaną między innymi przez dawnych uczniów gdańskiej uczelni, wśród których znaleźli się: Jan Bücher, Jan Dawid Czerniewski, Antoni Truhard (Truhardt, Truhart), Krzysztof Bogumił Rosenberg, Piotr Schwarz (Schwartz), Jan Gabriel Thilo. Podobnie żegnano Gabriela Joachima Weickhmanna (1734-1792) w Wittenberdze ${ }^{64}$, dawnego ucznia Gimnazjum Gdańskiego (od 1749 roku ${ }^{65}$ ) — z tym, że wśród ofiarodawców był tylko jeden gdańszczanin: Joachim Wilhelm Weickhmann (1737-1819) ${ }^{66}$. I kolejny tekst, tym razem nie uczniowski, lecz profesorski ${ }^{67}$. Autor pozostaje nie znany (czy był nim gdańszczanin?), natomiast wiemy, kim byli dedykujący, na karcie tytułowej bowiem czytamy: „Freunde und Landsleute”. Po tym zapisie następują nazwiska między innymi dawnych uczniów Gimnazjum Gdańskiego: Jana Adama Tritta, Jana Bogumiła Schnaasego, Daniela Bogumiła Weickhmanna, Ernesta Bogumiła Berniesa. A adresat wiersza? Był nim wspomniany już Daniel Gralath, syn burmistrza gdańskiego, również Daniela, który po nauce w Gimnazjum Gdańskim studiował w Królewcu po czym wyruszył w drogę powrotną do swego rodzinnego miasta. Właśnie z tej okazji dedykowano mu wspomnianą waletę.

Tyle potrafimy powiedzieć o autorach, ofiarodawcach i adresatach walet. Zanim przejdziemy do tekstów wypełniających owe dwu-, trzykartkowe druczki, odnotujmy jeszcze, że w Gdańsku powstawały nie tylko utwory pożegnalne, lecz także wiersze powitalne, skierowane do tych, którzy po latach studiów i podróży wracali do rodziny i przyjaciół. Niestety, podać można tylko dwa przykłady. Stosunkowo wcześnie powstał utwór Jana Samuela Vercha (1702-1764) ${ }^{68}$, witający Jana Konstantego Ferbera ${ }^{69}$, który w 1718 roku rozpoczął swoją

\footnotetext{
${ }^{63}$ Als der Wohledle und Wohlgelahrte Herr Herr Christoph Johann Tannenberg aus Danzig der H. Gottesgelahrheit wïrdiger Candidat und der Weltweisheit rïhmlichst Beflissener nach wohlgeendeten Academischen Jahren seine Reise nach Hause antrat begleiteten Denselben mit folgendem Gedichte nachstehende Landsleute und Freunde [...]. Im Jahr 1747 im April, Jena [1747]. Egz. BG PAN, sygn. Oe $1712^{\circ}$ adl. 32.

${ }_{6}^{4}$ Abschiedsgedicht dem Hochedlen und Wohlgelahrten Herrn Gabriel Joachim Weickhmann vornehmen Patricius aus Danzig bey Seiner Abreise aus Wittenberg gewidmet von einigen aufrichtigen Freunden [...] den 15 Januar 1759, Wittenberg [1759]. Egz. BG PAN, sygn. Oe $608^{\circ}$ adl. 46.

${ }^{65}$ Ksiega wpisów, op. cit., s. 336.

${ }^{66}$ Wymienieni Weickhmannowie byli braćmi stryjecznymi. Gabriel Joachim został w przyszłości sekretarzem miasta i rajcą, Joachim Wilhelm zaś - burmistrzem. Ten ostatni należał do inicjatorów założenia w Gdańsku towarzystwa literackiego.

${ }^{67}$ Dem Andenken des Hochädelgebohrnen und Hochgelahrten Herrn, Herrn Daniel Gralath, beyder Rechten Doktor, Berufenen öffentlichen ordentlichen Lehrer der Rechtsgelartheit und Geschichtkunde, wie auch Aufseher des akademischen Gymnasiums zu Danzig, bey seiner Abreise von der Hohen Schule zu Königsberg gewidmet von einigen Seiner Freunde und Landsleute... Den 13. Februarii 1764, Königsberg [1764]. Egz. BG PAN, sygn. Oe $598^{\circ}$ adl. 42.

${ }^{68}$ Niegdyś uczeń Gimnazjum Gdańskiego (Ksiega wpisów, op. cit., s. 300), później radca dworu, informator księcia Saksonii, Weimaru, Eisenach. Por. Patrizier, Bürger, Einwohner der Freien und Hansestadt Danzig in Stammund Namentaffeln vom 14.-18. Jahrhundert, gesammelt von D. Weichbrodt geb. v. Tidemann, [Bd. 4], [Kiel-Klausdorf 1992] s. 490.

${ }^{69}$ Johann Samuel Verch von Dantzig, Alumnus Backhuserianus, Als der [...] Herr Johann Constantin Ferber nach rühmlichst zuriick-gelegter Peregrination Anno 1725, den 2. October glïcklich wieder in Dantzig arrivirte, wolte seine gebührende Schuldigkeit glïckw'ünschend ablegen ein des Hoch-Edlen Ferberschen Hauses unterthänigster Diener..., Dantzig [1725]. Egz. BG PAN, sygn. Oe $82^{\circ}$ adl. 177a.
} 
edukację w Gimnazjum Gdańskim ${ }^{70}$ a studia uniwersyteckie ukończył w 1730 roku $^{71}$. Z późniejszych lat pochodzi wiersz Wilhelma Launa adresowany do Krystiana Wilhelma Fichtela $^{72}$, niegdyś ucznia Gimnazjum (od 1748 roku $^{73}$ ). Czy tego rodzaju tekstów powstało więcej? Zapewne tak; może uda się w przyszłości odnaleźć dalsze.

Autorzy, znani i — przeważnie — nie znani, zwracali się do wyjeżdżających w różnych formach wypowiedzi: w kantatach, propemptikach oraz w listach prozą.

Swoją napisaną u progu XVIII wieku waletę nazwał Schwertzlaff serenadą i śpiewem (Sing-Gedicht). Tymczasem jest ona przykładem świeckiej kantaty okolicznościowej, jej odmiany kameralnej, mającej jeszcze wiele wspólnego z madrygałami włoskimi, o czym świadczy zarówno deklamacyjne traktowanie słowa, jak i bogata rytmika.

Kantata Schwertzlaffa składa się z arii i partii chóralnych. Jako wykonawcy arii występują Fama, Temida, Apollo, Pallas Atena, Euzebiusz, chór zaś stanowią muzy. Ich wypowiedzi zamykają się w jednostkach kompozycyjnych o zróżnicowanej liczbie wersów i zróżnicowanej długości członów wersowych. Układ rymów jest raczej konsekwentny: dominują rymy dystychiczne (aabb) i krzyżowe (ababa).

Arie wypełnia pochwała dnia, dnia radości, w którym Behne i Hagdorn, adresaci kantaty, publicznymi wystąpieniami oratorskimi in Auditorio Athenaei Maximo zakończyli naukę w Gimnazjum Gdańskim, by następnie wyruszyć na studia do Frankfurtu nad Odrą. Obaj nazwani zostali — nie bez hiperbolizacji — synami muz (Musen-Söhne), synami Temidy, bogini prawa i praworządności, zasługującymi na wyróżnienie, na wieniec laurowy:

Denn wo Tugend-Fleiß wil grünen,

Muß auch blühen Ruhm und Ehr...

W ten sposób kantata przechodzi od pochwały dnia do pochwały przyszłych studentów, kończy się zaś następującymi słowami:

Gott führ Euch hin mit Ruhm und Freuden

An den Franckfurter Oder-Fluß

Und gebe, daß von Eurer Blüht

Das Vaterland den Nutzen sieht.

\footnotetext{
${ }^{70}$ Ksiega wpisów, op. cit., s. 301.

71 Jan Konstanty Ferber (ur. 1704 w Gdańsku) w przeciwieństwie do wielu przedstawicieli swego rodu kariery nie zrobił. Obraziwszy króla Augusta III, musiał opuścić miasto rodzinne; w roku 1746 - oskarżony o spiskowanie przeciw Fryderykowi II — został skazany na karę śmierci i następnie stracony (w Spandau).

${ }_{72}$ Wilhelm Lau, An den [...] Herrn Christian Wilhelm Fichtel, als Derselbe nach höchst rïhmlich absolvirten Studiis Academicis und glücklich geendigter Peregrination zum höchsten Vergnïgen Seiner hö̈hstgeehrtesten Eltern und sämmtlichen hohen Angehörigen gesund und glïcklich zu Hause arrivirte von [...]. 1757 den 20. Julius, Danzig [1757]. Egz. BG PAN, sygn. Oe $642^{\circ}$ adl. 85.

${ }^{73}$ Ksiegga wpisów, op. cit., s. 335.
} 
Nieco inaczej zaprojektowana została anonimowa kantata poświęcona Heiniusowi. Formalnie składa się ona - jak poprzednia — z arii i partii chóralnych oraz, dodatkowo, z kwestii wypowiadanych przez Patristenesa, Poreumatofilusa, Critesiusa. Podobnie jak w tamtej ukształtowana została budowa wersyfikacyjna, w podobnej — retorycznej — funkcji występuje też słowo. Natomiast odmiennie niż poprzednia - kantata anonima głosi pochwałę nie bohatera, lecz podróży, jej znaczenia. Jedna z arii zaczyna się od takiej myśli:

Wer sich höher denckt zu schwingen,

Darff nicht einen Ort ersehn...

myśli powracającej jak refren, również w wykonaniu chóru, któremu wtóruje Critesius mówiąc:

\section{[...] das Reisen macht den Mann.}

Dopiero w końcowych częśsiach kantaty pojawia się osoba Heiniusa, nazwanego synem muz (Musen-Sohn) - nie po to jednak, by stać się obiektem laudacji, lecz w tym jedynie celu, by wystąpić w roli adresata następującego życzenia:

Besteige nunmehro beglücket die Spitzen,

Wo Pallas als Führerin selbst sich gestellt...

Kantata nie należała do form szczególnie popularnych. Dominujące miejsce zajęły propemptika, a więc pieśni pożegnalne wywodzące się z tradycji greckiej i rzymskiej, w których występowały najczęściej takie motywy, jak żal z powodu rozstania, prośba o pamięć kierowana do wyjeżdżającego, życzenia pomyślności, również dla niego przeznaczone. Adresatem propemptikonu była zawsze osoba bliska nadawcy ${ }^{74}$.

W pieśni powstałej z okazji wyjazdu Jana Gotfryda Barendta jego rozstanie z miastem opłakują muzy, które swoim zachowaniem sprawiają, że

Apoll verließ den Göttersitz

Und kam bis an dem Weichsel-Strande...

Apollo w monologu wyjaśnia powody wyjazdu Barendta:

Er eilt nach jenem Saal-Athen.

Da will er seine Kunst erhöhn.

Mein Sohn, mein Aeskulap hat Ihn dahin gezogen.

Muzy z kolei zgłaszają swoje wątpliwości. Zawiązuje się rozmowa, lecz tworzące ją repliki nie prowadzą do rozluźnienia ładu intonacyjno-składniowego i wersyfikacyjnego, jaki autor

${ }^{74}$ J. Schnayder, Propemptikon, „Zagadnienia Rodzajów Literackich” t. I: 1958, s. 216-218. 
sobie narzucił. Przeciwnie, przyjęte w tym propemptikonie rygory są w pełni respektowane. Cała pieśń składa się z kilku 10-wersowych zwrotek z konsekwentnie realizowanym układem rymów: ababccdeed. Zachowując zgodność między granicą wersu a granicą jednostki składniowej, wyróżnia się wyrazistą rytmizacją. Czynnikiem sprzyjającym owej rytmizacji są paralelizmy syntaktyczne i — nade wszystko — prosty układ składniowy. Wyobrażenie o tym daje choćby końcowa zwrotka, zawierająca życzenia dla wybierającego się na studia medyczne Barendta:

So reise mit Vergnügen fort!

So liessen sich die Musen hören.

Gelange glücklich an dem Ort,

Da wo Apollens Söhne lehren!

Du lagest einst an unsrer Brust.

So lebe nun zu unsrer Lust!

Dies kannst Du von den Musen hoffen.

O Freund! wird dieses einst erfüllt;

Wird unser Schnen auch gestillt.

Es stehe Dir die Gunst der höchsten Vorsicht offen!

Zarówno w partiach monologowych jak i dialogowych propemptikonu powracają stale te same motywy: żal z powodu rozstania i życzenia na podróż i lata studiów. Jest tak również wówczas, gdy pieśń zaczyna się tak oto:

Kommt, ihr Dichter unsrer Zeiten!

Helft uns ein Gedicht bereiten;

Da ein Freund von Danzig zieht,

In dem ächte Kenntnis blüht!

Taką właśnie apostrofą — na miarę eposu - zaczyna się pieśń adresowana do Jana Krzysztofa Heima, w której również królują wspomniane motywy. Dochodzi do nich jeszcze jeden: prośba o pamięć. Motyw ten znajdujemy w końcowej zwrotce:

Daß der Schatz von Wissenschaften,

Dic in Deinem Geiste haften,

$\mathrm{Zu}$ besondrer Höhe steigt,

Hat Dein Fleis uns längst gezeigt.

Aechter Freund! Dein tiefes Wissen

Hat Dich unsrer Schaar entrissen.

Lebe wohl! Vergiß uns nicht!

Werde einst grosses Licht!

Tak kończą się bardzo liczne propemptika. Prośbę o pamięć zastępuje niekiedy życzenie powtórnego spotkania. Przytoczmy tu zwrotkę zamykającą utwór adresowany do Piotra Wilhelma Bichla (Biela) i Samuela Wilhelma Turnera: 
Euch folgt der treuste Wunsch für Euer Glück die Freundschaft seufzt nach jenem Augenblick, der Euch, die unsre Seele liebt, uns wieder in die Arme giebt.

W propemptikach, w których na pierwszym planie występuje motyw pożegnania, żal z powodu rozłąki nie jest tak silnie eksponowany. Przeciwnie, występuje w nich raczej akceptacja wyjazdu, oczywiście wyjazdu, którego celem są studia. Nie znany autor zwracał się do Biehla i Turnera w słowach pełnych podziwu i uznania dla ich decyzji:

Voll Durst nach Weisheit und mit starkem Schritt, geht Ihr voran zu höherem Gebiet der Musen, die mit sanfter Macht die Welt sich unterwürfig macht.

Inny autor - również anonim - swoje propemptikon związane z wyjazdem Daniela Ehregotta Hanscha, Daniela Ernesta Wagnera i Jana Piotra Ernesta Schefflera zaczął w tonacji zgoła żartobliwej:

Auch Ihr, o Freunde, reist aus Danzigs Mauren?

Soll dann die Freundschaft itzt beständig trauren,

Soll unsre Schule wüste stehn?

Hier flieht der Redlichste aus unsern Armen,

Und dort erscheint ein neues Abschiedskarmen,

Will jedermann aus Danzig gehn?

Muß unsre Leier nur von Klagen tönen,

Und unser Geist Gefühl und Schmerzen fröhnen?

Po tym żartobliwym wstępie pada dramatyczne pytanie:

Ach Freundschaft, warum hast du uns verbunden?

W dalszych wersach następuje jego rozwinięcie:

Vielleicht, daß dieser Augenblick,

Der uns von unsrer Freunde Seiten trennet,

Den bangen Schmerz, den nur das Scheiden kennet,

In unsre Seele giesen soll?

Wreszcie krótka odpowiedź:

Doch nein!

Gdyby nagrodą za przyjaźń i miłość miały być cierpienia i smutek:

Wo würden Freunde seyn... 
Propemptikon, choć pozostaje cały czas w kręgu myśli o rozstaniu, kończy się pogodnie; powtarza znane skądinąd życzenia dobrych dni.

Motywy występujące w pieśniowej odmianie propemptikonu pojawiają się również w odach. Powtarzają się w nich pochwały przyjaciół i podziękowania za przyjaźń. Nie są im też obce deklaracje o jej trwałości, wyrażane w stylu niekiedy patetycznym czy liryczno-retorycznym. Tak jest — przykładowo - w anonimowej Abschieds-Ode, złożonej z dziesięciu oktostychów (ababcdcd), adresowanej do Jana Karola Davidsona, Jana Natana Schultza i Krystiana Bogumila Sartoriusa:

Die Freundschaft die wir mit Vergnügen,

Bisher zusammen zugebracht,

Bleibe wie in ihren ersten Zügen,

Von uns mit gleicher Treu geacht.

Motyw przyjaźni występuje również w odzie Jana Leonarda Schlichera, pochodzącej z samego początku XVIII wieku. Rozpoczynające ją pytanie retoryczne:

So, Edler Rosenberg, wilstu von hinnen weichen?

wprowadza już od pierwszego wersu tonację bardzo uroczystą, którą podtrzymuje w dalszych wersach koncept ${ }^{75}$ - w stylu jeszcze barokowym - oparty na aluzji do nazwiska adresata ody, Jana Jerzego Rosenberga:

Komm denn du Grosser West mit deinem süssen Hauchen

Und trenne wie der Blitz was diese Rose quählt,

Laß diesen Rosenberg dem Aetna gleiche rauchen,

Der Rosen-Zucker streu, wo jener Asche hält,

So wird Dein Vater selbst in Deinen Augen schweben,

Wann Deiner Ahnen Glantz aus Deinen Thaten blitzt,

Wenn Du die Dornen wirst von Deinen Sinnen heben

Und zeigen wie Du seyst aus Rosen nur geschnitzt.

${ }^{75}$ Koncepty tego rodzaju — bliskie rebusowi czy lamigłówce — zdarzały się też później. Przykładem niech będzie zagadkowy zapis daty umieszczony pod tekstem walety adresowanej do Antoniego Henryka Kemny (Als der (Tit.) Herr Anthon Heinrich Kemna, der Rechten Beflissener seine bishero rühmlich gefïhrte Studia fortzusetzen im Jahr 1741 im Monat Julius von Danzig nach Hohen Schulen abreisete begleiteten Denselben mit einem wohlgemeinten Wunsche innenbenannte treue Freunde, Dantzig [1741]. Egz. BG PAN, sygn. Oe $1712^{\circ}$ adl. 12):

Dantzig im Jahr nach Christi Geburt,

Da viel Studenten nach Saxen rais'n furt

Und wir ein tausend und hunderten sieben

Nebst vier Kreutzer und einer Zahl schrieben

Den neun und zwantzigsten Julius,

Da ich Herr Kemna missen muß.

Rozwiązanie tej zagadki stanowi data pożegnania Kemny: 29 lipca 1741. 
Allusio ad nomen służy pochwale i bohatera ody, i jego przodków, laudacji będącej obok motywu przyjaźni istotnym komponentem tej ody.

Niektóre propemptika zdają się należeć do elegiaca poesis, za czym przemawiają obecne w nich motywy rozpamiętywania, skargi i lamenty, wyraziście zarysowane liryczne ,ja”. Skarżono się w nich na upływ czasu, na rozstanie z przyjacielem, i to w momencie, gdy jak to ujął autor walety skierowanej do Karola Fryderyka Schmelinga - utrwaliło się przekonanie:

Wie ein wahrer Freund beglückt...

Stwierdzeniu temu towarzyszyło przeświadczenie, że rozstanie rani — odwołajmy się do tego samego tekstu:

Da den Freund den wir verlohren,

Nie der Himmel wieder schenkt.

W słowach bezpośrednio do adresata propemptikonu skierowanych autor wyraża pragnienie zachowania w pamięci przez Schmelinga pozostających w Gdańsku przyjaciół, wdzięczność za przyjaźń, której wzór właśnie wyjeżdżający stworzył, wspomina o łzach i ostatnim pocałunku. Natomiast na drugim planie pozostają życzenia pomyślnej podróży.

Do elegijnej odmiany zbliżył się również anonimowy autor walety adresowanej do Artura Paynego, o czym świadczy już pierwsza zwrotka:

Schon nahet sie, die bange Abschiedsstunde,

Mit ihr der Trennung Schmerz!

Sie kömmt und schlägt des Scheidens tiefe Wunde

In Deiner Freunde Herz.

Można by zresztą przytoczyć dalsze strofy, w których depresyjna tonacja uczuciowa się utrzymuje, lecz nie sposób nie zauważyć zachęty do kontynuowania nauki. Payne mógł przeczytać:

Athene reichte Dir die Nectarschale,

Halb ihrer Weisheit voll:

Jetzt ruft sie Dich zu ihrem vollen Mahle,

Das sättigen Dich soll.

Po tych słowach następowały życzenia:

So reise denn, sey glücklich, Freund, und weihe

Der Weisheit Lehren Dich!

Der reichen Frucht von Deinem Fleiß erfreue

Noch spät die Nachwelt sich!

Karol Beniamin Feyerabend zaczął propemptikon od idylliczno-nostalgicznego obrazu: 
Wie herrlich strahlt in wolkenloser Ferne

Voll sanfter Ruh, du freundlichster der Sterne,

O holder Mond, Dein lieblich heller Schein!

Du breitest Ruhe auf die Lebens-Matten,

Die viel zu dulden, viel zu leiden hatten,

Wiegst sie in süße Hofnungs-Träume ein!

W następnej zwrotce dochodzi do głosu wyraziste ,ja":

Hier sitz' ich nun in Deinem blaßen Scheine,

Und denke dem, was ich verlor, und weine

Den Veilgeliebten meine Tränen nach!

po czym rozwija się opowieść o zmienności losu:

Wie wunderbar gehn doch des Schicksals Wege!

o przywiązaniu, przyjaźni, miłości i o rozstaniu z tym, który był oparciem w chwilach samotności. A w końcowej zwrotce znajdujemy podziękowania za wierność w przyjaźni, dedykację i życzenia:

Und nun! - hier dank ich Dir für Deine Treue!

Nimm dieses Denkmaal, das ich heut Dir weihe!

Ich gebe, was ich habe! - Kann ich mehr? -

Leb' wohl! Genieß des Lebens höchste Freuden, -

Und denk' an mich - und nimm, bevor wir scheiden,

Noch diese Thräne, und — dann keine mehr! -

I ta waleta - jak poprzednie - opiera się na organizacji stroficznej, wyrazistej rytmizacji, na zgodności między granicą wersu a granicą jednostki składniowej, na prostym układzie syntaktycznym, częstych paralelizmach leksykalnych i składniowych. Dodajmy, że propemptika pisano wierszem stychicznym i stroficznym. Zdarzały się zwrotki 4 - aabb), 6- (abcddc), 8- (aabbccdd) i 10-wersowe (ababccdeed).

Te same tony - smutnego rozpamiętywania — rozlegają się także w niektórych tekstach prozaicznych. Można się tu powołać na waletę adresowaną do Natana Fryderyka Froma, Walentego Bogusława Hackera i Jana Bogumiła Dragheima. Jak z elegii wzięte brzmią słowa choćby tego fragmentu:

Sie verlassen uns, vielleicht - der Himmel vernichte den schröcklichen Gedanken — vielleicht — auf ewig. Um sonst verbreitet nun der Frühling alle seine Schönheiten um uns herum. Umsonst sucht er unsere Sinne zu belustigen. Umsonst lacht uns das neue Grüne der Erden entgegen. Umsonst wirbelt die Nachtigall ihr thönendes Lied, und macht die umherliegenden Gegenden aufmerksam. Sie werden ohne uns die Anmuth des Frühlings feyern und 
entfernt von dem beglückten Danzig, von Ihren Freuden entfernt nur eingeschränkte Vergnügungen geniessen. (k. 3)

Nieznany autor tego tekstu powołuje się dalej na Christiana Fürchtegotta Gellerta, jednego z najwybitniejszych przedstawicieli niemieckiego oświecenia, i cytuje jego wiersz:

Sey ohne Freund, wie viel verliert dein Leben...

$\mathrm{Na}$ ogół jednak teksty pro memoria pisane prozą były od elegijnych nastrojów i nostalgicznych wynurzeń wolne; niosły z sobą zracjonalizowane wywody - oparte na podstawach filozoficznych, etycznych. Wobeser na przykład w swym Mnemosynonie z myślą o udającym się do Królewca Kuhnie snuł rozważania na temat szczęścia, a na pytanie, kto może być prawdziwie szczęśliwy, odpowiadał:

[...] nur derjenige [...], der seinen Verstand zur Wahrheit leitet, seinen Willen in der Tugend übt, der den edelsten Gebrauch von seinen Kräften macht, und immer mehr nach Vollkommenheit strebt; der seine Leidenschaften und Begierden bekämpft, und sich von dem Uebel, dessen Abwendung in seiner Gewalt ist, zu befreien sucht, der seine Würde als Mensch kennt, und sich nie dawider zu handeln erlaubt, der nur reine, hohe und würdige Vergnügungen genießt, und kurz, der weise und tugendhaft ist (s. 9).

Mądrość może być źródłem szczęścia, bo kształci duszę, uszlachetnia ludzkie zdolności i talenty, wysubtelnia uczucia i obyczaje. Z równie wysoką oceną autora przytoczonych słów spotkała się cnota. O niej myślał Sokrates, gdy mężnie sięgnął po cykutę; dzięki niej może człowiek - według Ewalda von Kleista, przez Wobesera przywołanego - „das Meer des Lebens durchschiffen, durch sie den Haafen des Glück's erreichen" (s. 16-17). Na tych ogólnych stwierdzeniach zbudowane zostały uwagi bezpośrednio do Kuhna skierowane:

[...] fahre fort die Wissenschaften zu lieben; suche Deine Kentnisse zu erweitern, um einst ein recht nützliches Mitglied des Staates zu werden; fahre aber auch fort, die Tugend zu lieben, ohne sie kanst Du nicht glücklich seyn... (s. 20)

Do niego również zaadresowane zostały końcowe życzenia — jak we wszystkich waletach - powtarzające prośbę o pamięć:

Mögte Dein Leben wie ein entwölkter Frühligsmorgen vorübereilen; mögte es so rein, wie der Aether, voll Harmonie wie die Stimmen des Waldes seyn; mögte es von guten Thaten umkränzt Dich immerdar empfinden lassen, daß wir nur durch Weisheit und Tugend glücklich seyn können. - Nimm aber auch, geliebter Freund, bey unsrer letzten Umarmung die Bitte, uns so zu lieben, wie wir Dich stets lieben werden, und den innigst eifrigen Wunsch: sey glücklich, wie je ein Sterblicher es werden kann, und lebe immer, immer wohl. (s. 22-23). 
Zupełnie wyjątkowe miejsce wśród walet zajmuje Almanach der Freundschaft ofrarowany Karolowi Fryderykowi Benedyktowi Cosakowi. Składa się on z dwóch części: kalendarzyka na rok 1796 oraz z właściwego almanachu obejmującego niemieckie, łacińskie, angielskie i francuskie teksty wierszowane i prozaiczne, przeznaczone - jak podaje autor — na pierwsze i drugie półrocze. W wierszach przeważają motywy przyjaźni („Freundschaft hat so manche Stunden...”) i rozstania („Wir scheiden - meine Seele nicht”), upływu czasu („Fugit irrepabile tempus") i szczęścia, mądrości i cnoty. Niektóre z nich odzywają się nawet w pieśni An Bacchus ('śpiewanej na melodię Ich frage nichts nach Ruhm und Geld), zaczynającej się inwokacyjnie komm gott des Weines, komm herab. Z innych tekstów wymienić należy parafrazę ody Horacego (Carm. I, 26), zaczynającą się od słów: „Traurigkeit ihr lieben Musen!” Czas, by wspomnieć o prozie. Zacznijmy od dopiero co wymienionego Horacego. Pochodzące z jego ody (Carm. III, 30) słowa „Non omnis moriar” zostały opatrzone krótkim, jednozdaniowym komentarzem:

Heil dem, der dies am Ende seiner Tage mit Ueberzeugung sagen kann.

Autor Almanachu przytoczył tego rodzaju tekstów więcej, często obiegowych, funkcjonujących na zasadzie ogólnie znanych maksym - w oderwaniu od utworów, z których się wywodziły. Wprowadził do swego zbiorku zwięźle zapisane myśli. Niech przykładem będą następujące słowa:

Man höret eine klägliche Stimme und bitteres Weinen auf der Höhe...

umieszczone pod tytułem die Schmerzen der Trennung. Wśród tekstów prozaicznych spotkać również można miniaturowe opowiastki o aniołach, aniele pamięci i aniele nadziei, towarzyszących człowiekowi przez całe życie, o Diogenesie poszukującym człowieka. Odnosi się wrażenie, że autor kształtował Almanach na wzór imionnika: wpisywał sentencje, obiegowe i własne, wiersze swojego pióra i parafrazy obcych tekstów (na przykład Horacego), to wszystko, z czym pragnął w chwili rozstania podzielić się z przyjacielem. Autentyczny sztambuch, oczywiście, nie powstał, nie był bowiem dziełem wielu umysłów i rąk, a poza tym: nie pozostał w rękopisie, ukazał się w druku.

\section{Quodlibet polifoniczny. Imionniki drukowane}

Obecnie w polu naszego widzenia znajdzie się quodlibet polifoniczny, znajdą się zbiorki złożone $\mathrm{z}$ tekstów różnych autorów, innymi słowy: znajdą się drukowane sztambuchy, imionniki. Zacznijmy od relatywnie wczesnej publikacji dedykowanej Janowi Rajnoldowi Hintzowi (Hinzowi) ${ }^{76}$, uczniowi Gimnazjum Gdańskiego od 1735 roku $^{77}$, wyruszającemu pięć lat

${ }^{76}$ Als der Wohlädle und Wohlgelahrte Herr Johann Reinhold Hintz der Weltweisheit und Rechtsgelehrsamkeit Beflissner sein rühmlichst geführtes Studiren fortzusetzen im Monat September 1740 von hier nach Königsberg abgieng begleiten Denselben mit folgenden Zeilen innen benannte Freunde, Danzig [1740]. Egz. BG PAN, sygn. Oe $1712^{\circ}$ adl. 9. 
później na studia do Królewca. Na tomik ten złożyły się teksty pisane prozą i wierszem po łacinie, po niemiecku i po francusku. W'́ród autorów byli Jan Samuela Ferber, Krystian Gram (Gramm), Wilhelm Wolters, Beniamin Reimer, Michał Mündel, Jan Dawid Hanke (Hancke), Tomasz Idzi Hoppe, Michał Bogumił Treuge (z Malborka) i Antoni Truhardt (Truhard, Truhart). Niektórzy z nich - Ferber, Gram, Hoppe, Wolters, Reimer, Treuge i Truhardt byli kolegami gimnazjalnymi Hintza ${ }^{78}$. Analogicznie jest w wypadku innego druku również z 1740 roku $^{79}$. Wśród autorów dwukartkowej publikacji, dedykowanej Natanowi Bogumiłowi Suterowi, uczniowi Gimnazjum od 1735 roku $^{80}$, wybierającemu się na studia do Saksonii, byli Beniamin Groddeck i Jan Kornad Eichhorn, koledzy gimnazjalni, obaj zapisani w metryce w 1729 roku $^{81}$, oraz Jan Michał Wundsch, młodszy kolega, którego nazwisko figuruje w metryce pod rokiem $1734^{82}$. Identycznie wypadnie odebrać - tym razem czterokartkowy — druczek poświęcony Dawidowi Ludwikowi de la Motte ${ }^{83}$, uczniowi Gimnazjum Gdańskiego od 1735 roku $^{84}$. W gronie autorów znaleźli się znani nam już Wundsch, Wolters, Remer, lecz doszli dalsi, również uczniowie (z lat 1732-1740 ${ }^{85}$ ): Marcin Gram (Gramm), brat wymienionego wcześniej Krystiana, Krystian Bogumił Rosenberg, Jeremiasz Moll, Jan Karol Weydmann (Weidmann), Jan Joachim Laurenz (Laurens), Jan August Siegfried, Wilhelm Gordon, Samuel Henryk Mogge, Krystian Waldau, Adam Krzysztof Zachariae. Z roku 1741 pochodzi imionnik dedykowany Antoniemu Henrykowi Kemnie ${ }^{86}$, uczniowi Gimnazjum od 1740 roku $^{87}$, z wpisami Krzysztofa Jana Tannenberga, Daniela Hermana Richtera, Jana Teofila Pegelaua, Salomona Jantzena, Jana Büchera i Antoniego Truhardta — jego kolegów figurujących w metryce gimnazjalnej w latach 1732-1740 88 . Nieco później — w 1748 roku $^{89}$ — ukazal się sztambuch z dedykacją dla Filipa Sylwestra Lürseniusa i Karola Joachima von Behra, uczniów gimnazjum od 1744 (Lürsenius) i od 1745

${ }_{77}$ Księga upisów, op. cit., s. 322.

${ }^{78}$ Ibidem, s. 320, 322, 324, 325, 327.

79 Als der Wohl-Edle und Wohl-Gelahrte Herr Nathanael Gottlieb Suter der Gottesgelahrtheit Beflissener 1740 den 27. Julii von hier nach Sächsischen hohen Schulen verreisete wolten Ihm mit diesen wenigen Zeilen begleiten innen benannte Freunde, Danzig [1740]. Egz. BG PAN, sygn. Oe $1712^{\circ}$ adl. 31.

${ }^{80}$ Ksiega wpisów, op. cit., s. 323.

81 Ibidem, s. 313-314.

82 Ibidem, s. 321.

${ }^{83}$ Als der (Tit.) Herr David Ludwig de la Motte, der Gottesgelahrtheit Beflissener, sein allhier bishero rïhmlichst gefihhrtes Studiren fortzusetzen, im Jahr 1741 im Monat August von Danzig nach Hohe Schulen verreiste, wolten Ihn mit wohlgemeinten Wïnschen begleiten, innenbenannte treue Freunde, Danzig [1741]. Egz. BG PAN, sygn. Qb $100884^{\circ}$ adl. 13.

${ }^{84}$ Ksiega wpisów, op. cit., s. 321.

85 Ibidem, s. 319, 320, 322-325, 327.

${ }^{86}$ Als der (Tit.) Herr Anthon Heinrich Kemna, der Rechten Beflissener seine bishero rïhmlich geführte Studia fortzusetzen im Jahr 1741 im Monat Julius von Danzig nach Hohen Schulen abreisete begleiteten Denselben mit einem wohlgemeinten Wunsche innenbenannte tretue Freunde, Danzig [1741]. Egz. BG PAN, sygn. Oe $1712^{\circ}$ adl. 12.

87 Ksiega wpisów, op. cit., s. 327.

${ }^{88}$ Ibidem, s. 318, 325-327.

${ }^{89}$ Als die Wohlädle und Wohlgelahrte Herren, Herr Philip Silvester Lürsenius der Arzeney-Wissenschafft Beflissener nach Leyden und der Wohlgebohrne Herr Carl Joachim von Behr der Rechts-Gelehrsamkeit Beflissener nach Rostock zu 
roku (Behr $)^{90}$. Wpisu dokonali koledzy z tego samego środowiska, to znaczy uczniowskiego i studenckiego, nie zawsze jednak wywodzący sic̨ z Gimnazjum Gdańskiego. Uczelnię tę reprezentowali między innymi Jan Krzysztof Heim, Wilhelm Pilatzki, Arnd Janzen, Jan Efraim Golz, Krystian Fryderyk Pantaenius, Wilhelm Henryk Penski.

W 1757 roku opublikowano dwa tomiki dedykowane Janowi Bogumiłowi Bartoldiemu i Joachimowi Fryderykowi Weickhmannowi ${ }^{91}$ oraz Franciszkowi Jakubowi Schalckowi ${ }^{92}$. Adresaci tych walet pobierali nauki w Gimnazjum Gdańskim ${ }^{93}$. To samo powiedzieć można o autorach tekstów. Oto niektórzy z nich: Michał Dawid Lange, Fryderyk August Deschner, Jan Michał Wulff, Joachim Wilhelm Weickhmann, Karol Beniamin Raschke, Jan Bernard Gregorovius, Jan Adam Tritt, Adam Ludwik Carpow, Jan Renner. Naukę w Gimnazjum Gdańskim zaczynali oni w latach $1750-1756^{94}$.

Równicż w późniejszych latach ukazywały się podobne imionniki, zwłaszcza w dziesięcioleciu 1770-1780. Dedykowano je Krystianowi Bogumiłowi Perschkemu i Janowi Fryderykowi Steinhöfelowi ${ }^{95}$, Henrykowi Jakubowi i Janowi Bogumiłowi Martensom ${ }^{96}$, Michałowi Mylckemu, Janowi Rohlederowi i Jakubowi Fryderykowi Benthienowi ${ }^{97}$, Karolowi Ernestowi Kositzky'emu i Filipowi Adolfowi Lampemu ${ }^{98}$, Janowi Michałowi Kiepkemu i Janowi Henrykowi Schmidtowi ${ }^{99}$ oraz Arnoldowi Bogumilowi Ehlerowi i Gabrielowi

Fortsetzung ihrer gelehrten Bemïhungen im Jahr 1748 am 14ten des Augustmonats von Danzig abreiseten, begleiteten Dieselbe mit folgenden Wïnschen die in diesen Blättern benannte Freunde, Danzig [1748] Egz. BG PAN, sygn. Oe $1712^{\circ}$ adl. 19.

90) Ksiega wpisów, op. cit., s. 331-332.

${ }^{91}$ Ode. An die [...] Herm Johann Gottlieb Bartoldi, der Gottesgelahrtheit Beflissenen und Herm Joachim Friedrich Weickhmann, der Rechtsgelehrsamkeit Beflissenen bey Ihrer Abreise auf die hohe Schule nach Rostock. Im Namen hinten benannter Freunde. Danzig, 1757 im Herbst-Monat, [Danzig 1757]. Egz. BG PAN, sygn. Oe $642^{\circ}$ adl. 91.

92 Als der [...] Herr Frantz Jacob Schalck um seine Erkänntnis in der Gottesgelahrheit und Weltweisheit zu vergrössern im Herbstmonat des 1757 sten Jahres nach Rostock verreiste, bezeigten bey seiner Abreise ihre Freundschaft Innengenannte, Danzig [1757]. Egz. BG PAN, sygn. Oe $642^{\circ}$ adl. 92.

${ }_{93}$ Ksiega wpisów, op. cit., s. 331-332, 340.

${ }^{94}$ Ibidem, s. 337-345.

${ }_{95}$ An die [...] Herren Christian Gottlieb Perschke und Johann Friedrich Steinhöfel, der Gottesgelahrtheit rïhmlichst Beflissene, bei Ihrer Abreise nach Göttingen und Leipzig von Innenbenanten Freunden. Im Monath September 1771 , Danzig [1771]. Egz. BG PAN, sygn. Oe $89744^{\circ}$.

${ }^{9}$ Denen [...] Herren Hern Heinrich Jacob Martens und Herrn Johann Gottlieb Martens, beyder Rechte rïhmlichst Beflissenen, bei Ihrer Abreise nach Göttingen, zum Denkmal aufrichtiger Freundschaft geweihet von Innenbenannten. Im September Monathe des 1773 sten Jahres, Danzig [1773]. Egz. BG PAN, sygn. Oe $84532^{\circ}$.

${ }_{97}$ Denen [...] Herren Michael Mylcke, Johann Rohleder und Jacob Friedrich Benthien, der Gottesgelahrtheit rïhmlichst Beflissenen, bey Ihrer Abreise nach Königsberg und Greiffswalde zum Denkmal aufrichtiger Freundschaft getveihet von Innenbenannten. Im Monat September des 1773sten Jahres, Danzig [1773]. Egz. BG PAN, sygn. Oe $87142^{\circ}$.

${ }_{98}$ An Herrn Kositzky und Herm Lampe, der Arzeneiwissenschaft rïhmlichst Belfissene. Gewidmet bei Ihrer Abreise vom Danziger Gymnasio nach der hohen Schule Göttingen von Ihren Freunden. 1773. Im Monath März, Danzig [1773]. Egz. BG PAN, sygn. Oe $708^{\circ}$ adl. 1; Oe $768^{\circ}$ adl. 2.

${ }^{99}$ An di[e] Wolädle und Wolgelarte Herren Herrn Johann Michael Kiepke, der Gottesgelartheit rümligst Beflissenen, und Herrn Johann Heinrich Schmidt, beider Rechte rïmligst Beflissenen. Im Monat April des 1779sten Jahres, Danzig [1779]. Egz. BG PAN, sygn. Oe $608^{\circ}$ adl. 2. 
Bogumiłowi Reinickowi ${ }^{100}$. Aż sześciu spośród wymienionych wpisano w metryce Gimnazjum Gdańskiego w tym samym - 1769 — roku ${ }^{101}$, pozostałych w latach $1770-1774^{102}$.

A co można powiedzieć o autorach? To samo, co o wielu innych, wcześniej wymienionych. Byli rówieśnikami wyjeżdżających na studia lub ich młodszymi kolegami z Gimnazjum Gdańskiego. Część z nich podjęła już naukę za granicą. Wymieńmy niektórych: Efraim Lindner, Jan Daniel Richter, Samuel Bogumił Weickhmann, Samuel Benedykt Flander, Aleksander Bertold Wichers, Jan Efraim Walter, Jan Bogumił Martens, Karol Fryderyk Teodor Bertling, Karol Ernest Kositzki, Jakub Fryderyk Benthien, Jan Jakub Plaga (wszyscy rozpoczęli naukę w Gimnazjum Gdańskim w tym samym roku - 1769), Jan Erdman Felskau, Jan Michał Kiepke, Abraham Beniamin Krüger, Wilhelm Ernest Elganowski.

W następnym dziesięcioleciu opublikowano nie mniej liczne imionniki - ofiarowane Janowi Gotfrydowi Barendtowi i Karolowi Gotfrydowi Schopenhauerowi ${ }^{103}$, Absalonowi Fryderykowi Marxowi ${ }^{104}$, Karolowi Beniaminowi Barendtowi i Karolowi Efraimowi Roepellowi $^{105}$, Janowi Ludolphowi Ratzkiemu ${ }^{106}$, Janowi Krystianowi Ayckemu ${ }^{107}$, pobierającym - jak poprzednicy - naukę w Gimnazjum Gdańskim (do metryki wpisani zostali w latach 1779-1782 ${ }^{108}$. Autorzy zgodnie z tradycją wywodzili się w większości z tych samych - uczniowsko-studenckich — kręgów. Wiele nazwisk już znamy, dodajmy kilka nowych: Absalon Fryderyk Marx, Jan Fryderyk Oyer, Daniel Sommerfeldt, Jonatan Ernest Gotfryd Ehwald, Ditmer Wilhelm Lösekann. I oni byli uczniami Gimnazjum Gdańskiego.

Wreszcie końcowe lata XVIII wieku. Ukazały się wówczas sztambuchy ofiarowane Karolowi Janowi Fryderykowi von Rosenberg Gruszczinskiemu (Gruszczynski) i Karolowi

\footnotetext{
${ }^{100}$ Denen Wohledlen und Wohlgelahrten Herren Herrn Arnold Gottlieb Ehler, beyder Rechte rühmlichst Beflissenen, und Herrn Gabriel Gottlieb Reinick, der Arzneygelahrtheit rïhmlichst Beflissenen, bey Ihrer Abreise von Danzig nach Göttingen gewidmet von Innenbenannten. Im Monat März des 1779sten Jahres, Danzig [1779]. Egz. BG PAN, sygn. Oe $598^{\circ}$ adl. 24.

${ }^{101}$ Ksiega wpisów, op. cit., s. 346-348.

${ }^{102}$ Ibidem, s. 351-356.

${ }^{103}$ An die [...] Herren, Herrn Johann Gottfried Barendt, der Gottesgelahrtheit rühmlichst Beflissenen und Herrn Carl Gotffried Schopenhauer, beyder Rechte rühmlichst Beflissenen. Bei Ihrer Abreise vom Danziger akadem. Gymnasium nach der hohen Schule zu Göttingen von Ihren Freunden gewidmet. Im Monath September 1782, Danzig [1782]. Egz. BG PAN, sygn. Oe $708^{\circ}$ adl. 2.

${ }^{104}$ Unserm abreisenden Freund dem [...] Herrn Absalon Friedrich Marx, der Gottesgelahrtheit rühmlichst Beflissenen. Im Monat April 1784, Danzig [1784]. Egz. BG PAN, sygn. Oe $708^{\circ}$ adl. 3.

${ }^{105}$ Unsern abreisenden Freunden, den [...] Herren, Herrn Karl Benjamin Barendt und Herrn Karl Ephraim Roepell, beider Rechte rühmlichst Beflissenen. Danzig, im Augustmonat 1785, [Danzig 1785]. Egz. BG PAN, sygn. Oe $708^{\circ}$ adl. 4 .

106 Unserm abreisenden Freund, dem [...] Herm Johann Ludolph Ratzki, beyder Rechte rühmlichst Beflissenen. Im Lenzmonde des 86sten Jahres, Danzig [1786]. Egz. BG PAN, sygn. Oe $708^{\circ}$ adl. 5.

${ }_{107}$ Ihrem geliebten Freunde Herrn Johann Christian Aycke, der Rechte rühmlichst Beflissenen, zum freundschaftlichen Andenken gewidmet von Innenbenannten. Im September 1788, Danzig [1788]. Egz. BG PAN, sygn. Oe $708^{\circ}$ adl. 7. ${ }^{108}$ Ksiega wpisów, op. cit., s. 361-364.
} 
Lobegottowi Hackerowi ${ }^{109}$, Jerzemu Ludwikowi Kummerowi ${ }^{110}$, Janowi Bogumiłowi Stelterowi i Samuelowi Leopoldowi Schimmingowi ${ }^{111}$, Karolowi Gotthilfowi Gronertowi i Janowi Michałowi Langwaldowi ${ }^{112}$ oraz Samuelowi Bogumiłowi ${ }^{113}$ Schefflerowi ${ }^{114}$, będącym — z wyjątkiem tego ostatniego — uczniami Gimnazjum Gdańskiego. Część z nich wpisana została w metryce w tym samym roku, zwłaszcza w $1790^{115}$. Z tego samego grona wywodzili się — w większości -- autorzy tekstów zamieszczonych w imionnikach. Wymieńmy przykładowo następujących: Jan Jakub Schalk, Samuel Salomon Schneider, Krystian Bogumił Prückelmeier, Jerzy Teodor Dietrich, Daniel Fryderyk Rösner, Karol Fryderyk Benedykt Cosak (Cosack), Jan Michał Langwald, Jerzy Ludwik Kummer, Bogumił Samuel Walter, Jan Bogumił Stelter, Karol Lobegott Hacker, Ernest Beniamin Badengoth, Jan Samuel Schultz, Jerzy Fryderyk Fleischer, Jan Dawid Weichbrodt, Jan Dawid Friederichs. Ten i ów mógł o sobie napisać: itineris socius, towarzyszył bowiem wyjeżdżającemu na uniwersytet, by wraz z nim podją́ studia.

Nazwiska tu w różnych kontekstach przywoływane — niektóre wielokrotnie — świadczą, że noszący je uczniowie i studenci występowali często w dwóch rolach: jako autorzy wpisów, i to wcale często w dwóch, a nawet trzech imionnikach, oraz jako adresaci przygotowanych z myślą o nich drukowanych sztambuchów. Działo się tak bodaj od początku interesującego nas tutaj stulecia. Zacznijmy od Jana Konrada Eichhorna ${ }^{116}$, wymienionego już w gronie autorów. W publikacji jemu dedykowanej znajdujemy niemal wszystkie nazwiska znane już skądinąd. Z nowych wymieńmy Daniela Hermana Richtera, Kaspra Henryka

${ }^{109}$ Dem Andeken unserer unvergeßlichen Freunde Herrn Carl Johann Friedrich von Rosenberg Gruszczinski, der Oeconomie Beflißenen, und Herrn Carl Lobegott Hacker, der Gottes Gelahrtheit Beflißenen, bey Ihrer bevorstehenden Abreise auf die hohe Schule nach Königsberg. Gewidment von Innenbennanten und ïberreicht von [Samuel Salomo] Schneider, [G. H. Th.] Pobowski und [Carl Friedrich Benedict] Cosack. Im März 1793, Danzig [1793]. Egz. BG PAN, sygn. Oe $778^{\circ}$ adl. 3.

${ }^{110}$ Unserm abreisenden Freunde Herrn Herrn George Ludwig Kummer, beider Rechte rühmlichst Beflissenen, bey Seiner Abreise von unserm akademischen Gymnasio auf die hohe Schule nach Frankfurt an der Oder gewidmet von Innenbenannten und überreicht von Johann Karl Alberti, Arthur Payne, Karl August Stelter. Im September 1794, Danzig [1794]. Egz. BG PAN, sygn. Oe $708^{\circ}$ adl. 9 i Oe $778^{\circ}$ adl. 5.

"II Neues Taschen-Buch. Denen Herrn Herrn J[ohann] G[ottlieb] Stelter und Siamuel] L[eopold] Schimming bey Ihrer Abreise gewidmet von Innbenannten, Danzig [po 1790]. Egz BG PAN, sygn. Qb $100884^{\circ}$ adl. 5.

${ }^{112}$ Zum Andenken der Freundschaft dem Herrn, herrn Carl Gotthilf Gronert, d. G. G. B., bey seiner Abreise auf die hohe Schule nach Halle und dem Herrn, Herm Johann Michael Langwald, d. G. G. B., bey seiner Abreise auf die hohe Schule nach Königsberg im Namen aller Innenbenannten errichtet von [Peter] Barck, [Johann Samuel] Schultz, [Johann David] Weichbrodt, [Carl Abraham] Voßberg. Danzig, im September 1795, [Danzig 1795]. Egz. BG PAN, sygn. Oe $778^{\circ}$ adl. 7. ${ }^{113} \mathrm{~W}$ sztambuchu ofiarowanym Schefflerowi nie podano jego imion. Wydaje się, że chodzi tu o Samuela Bogumiła Schefflera (ur. w 1775 roku w Gdańsku), który po studiach w Królewcu i Halle został pastorem w Koszwałach (Gottswalde). Por. L. Rhesa, Kurzgefasste Nachrichten von allen seit 1775 an den evangelischen Kirchen in Ostpreuszen anestellten Predigern..., Königsberg 1834, s. 96.

${ }^{14}$ Noth und Hülfs-Büchlein für Reisende. Unserm allgemein geliebten Freunde [Samuel Gottlieb] von Scheffler, der Theol. Stud., bei Seiner Abreise nach Königsberg, Danzig 1796. Egz. BG PAN, sygn. Oe $778^{\circ}$ adl. 9.

115 Ksiega wpisów, op. cit., s. 368-372 (lata 1786-1791).

${ }^{116}$ Als der(Tit.) HerrJohann Conrad Eichhorn der Gottes-Gelahrtheit Befliessener sein alhier rühmlichst geführtes Studiren fortzusetzen im Jahr 1741 den 29 Julius von Danzig nach Sächsischen hohen Schulen abreisete begleiteten Denselben mit einigen aufrichtigen Wïnschen innenbenannte Freunde, Danzig [1741]. Egz. BG PAN, sygn. Qb $100884^{\circ}$ adl. 16. 
Eberhardiego, Jana Adolfa Oesterreicha, Jana Büchera, Salomona Jantzena, Dawida Sachsa wywodzących się - bez wyjątku - spośród uczniów (zapisanych głównie w latach 1738-1739) Gimnazjum Gańskiego ${ }^{117}$. Wymienione nazwiska powtarzają się w publikacji adresowanej do Tomasza Idziego Hoppego ${ }^{118}$, ucznia Gimnazjum Gdańskiego od 1737 roku $^{119}$, Karola Hanmanna i Beniamina Groddecka ${ }^{120}$, uczniów z lat 1729 (Groddeck) i 1732 (Hanmann) ${ }^{121}$. Dwaj z nich - Hoppe i Groddeck - utrwalili się już w wcześniej wymienionych sztambuchach. Przykładów tego typu można podać więcej. Ograniczmy się do kilku. Najpierw tomik związany z osobami Michała Wunscha, Jana Dawida Hankego i Daniela Hermana Richtera ${ }^{122}$, uczniów Gimnazjum Gdańskiego, z których Hanke, Richter i Michał Wittwerck, wymieniony również na karcie tytułowej omawianej walety, rozpoczęli naukę w 1732 roku $^{123}$, Wunsch - dwa lata później ${ }^{124}$. Z powstałych w następnych latach przypomnijmy tomik dedykowany Samuelowi Benedyktowi Flanderowi, Aleksandrowi Bertoldowi Wichersowi i Gotfrydowi Eilhardowi Reinickowi (Reinick, Reincke) ${ }^{125}$, uczniom Gimnazjum od 1769 roku ${ }^{126}$. Teksty zamieszczone w tym tomiku podpisali również uczniowie Gimnazjum Gdańskiego, przeważnie z lat 1769-1770, z niewielkim udziałem wpisanych w latach 1772-1773 ${ }^{127}$. Wymieńmy ich: Jerzy Bogumił Dittmann, Karol Otto Zabani (Zabany), Samuel Bogumił Weickhmann, Daniel Ludwik Setau, Karol Bogumił de Cedernstolpe, Karol Fryderyk Ehler, Jan Beniamin Matthesius, Jan Krystian Walter, Karol Fryderyk Teodor Bertling, Adrian Fryderyk Engelcke, Karol Jeschcke, Walenty Henryk Zernecke, Piotr Andrzej Witzgall, Bogumił Albrecht Gottel, Jan Fryderyk Schollyn, Daniel Bogusław Pauli, Jan Krystian Volkmann (Volckmann), Jan Erdmann Felskau, Emanuel Konstanty Fahr, Jan Jakub Plaga. Sięgnijmy jeszcze po zbiorek dedykowany Janowi Micha-

\footnotetext{
117 Ksiega wpisów, op. cit., s. 318, 325-327.

${ }_{118}$ Als der Wohlädle und Wohlgelahrte Herr Thomas Aegidius Hoppe der Rechten und Weltweisheit eifrigst Beflissener sein rïhmlich gefïhrtes Studiren weiter fort zu setzen von hier nach Sächsischen Hohenschulen ging begleiteten Denselben mit folgenden Wïnschen innenbenannte Freunde, Danzig 1741. Egz. BG PAN, sygn. Oe $1712^{\circ}$ adl. 11.

${ }^{119}$ Ksiegga upisów, op. cit., s. 324.

${ }^{120}$ Als die Wohlädlen und Wohlgelahrten Herrn Carl Hanmann und Benjamin Groddeck der Gottesgelahrtheit Beflissene Ihre bisher riihmlichstgeführte Studia fortzusetzen im Jahr 1741 den 30 Jun. von Danzig nach Sächsischen Hohen Schulen abreiseten, begleiteten Selbige innen benannte Freunde, Danzig [1741]. Egz. BG PAN, sygn. Oe $1712^{\circ}$ adl. 7.

121 Ksiega wpisów, op. cit., s. 313 i 318.

${ }^{122}$ Als die Herren Michael Wunsch, der Gottesgelahrtheit, Johann David Hanke, der Rechtsgelahrtheit, Michael Wittwerck, der Arzeneykunst, und Daniel Hermann Richter, der Gottesgelahrtheit Beflissene Ihre bishero in Danzig rihhmlich geführte Studia weiter fortzusetzen sich im Jahr 1742 den 3 September nach Sächsischen hohen Schulen begaben begleiteten Dieselben mit folgenden wohlgemeinten Glückwünschen innen benannte treue Freunde, Danzig [1742]. Egz. BG PAN, sygn. Oe $1712^{\circ}$ adl. 39.

123 Ksiega wpisów, op. cit., 318.

124 Ibidem, s. 321.

${ }_{125}$ An die Wohlädle und Wohlgelahrte Herren, Hern Samuel Benedict Flander, Herm Alexander Barthold Wichers, und Herrn Gottfried Eilhard Reinick, der Rechtsgelahrheit riihmlichst Beflissene. Gewidmet bei Ihrer Abreise vom Danziger Gymnasio nach den hohen Schulen Göttingen und Wittenberg von Ihren Freunden. 1774 im Monate März, Danzig [1774]. Egz. BG PAN, sygn. Oe $64258^{\circ}$.

${ }^{126}$ Ksiegga wpisów, op. cit., s. 348 i 351.

${ }^{127}$ Ibidem, s. 346-348, 351-355.
} 
łowi Fryderykowi Mundtowi ${ }^{128}$ (zapisanemu w metryce gimnazjalnej w 1775 roku $^{129}$ ) wyruszającemu na studia do Jeny. Figurujące w nim nazwiska należą do uczniów Gimnazjum Gdańskiego. Oto przykłady: Karol Bogusław Scholtz, Krystian Michał Natan Gerber, Karol Wilhelm Schimming, Abraham Gerstenberger, Franciszek Bellair, Jan Jakub Foss, Jan Adolf Hofmeister (Hoffmeister), Karol Aleksander Görke (Goercke), Jan Krzysztof Schulz, Paweł Jakub Rosenthal. Wszyscy zapisani zostali w metryce gimnazjalnej w latach 1776-1781 130 . I jeszcze jeden imionnik — z roku 1797 — dedykowany Ernestowi Beniaminowi Badengothowi, gdy ten wyruszał na uniwersytet w Królewcu ${ }^{131}$. Badengoth był uczniem Gimnazjum — od 1791 roku $^{132}$, a wpisy w almanachu były dziełem jego gimnazjalnych kolegów. Dość wymienić tu - przykładowo - Joachima Augusta Ludwika Waltera, Karola Augusta Steltera, Jana Ludwika Gregoroviusa, Jana Henryka Peterssena, Natana Gotfryda Schultza, Karola Augusta Vieritza, Franciszka Teodora Józefa Henryka Krakowa i Jana Beniamina Pahla, zapisanych w metryce Gimnazjum w latach 1787-1795 133 .

Na specjalną uwagę zasługują autorzy, których nazwiska pojawiają się w wyjątkowo licznych imionnikach. Chodzi tu między innymi o Joachima Wilhelma Weickhmanna, ucznia z 1752 roku $^{134}$, Jana Rennera, ucznia z 1756 roku $^{135}$ i Fryderyka Deschnera z 1782 roku ${ }^{136}$. Im także dedykowano stosowne walety ${ }^{137}$. Weickhmann - dodajmy musiał należeć do grona szczególnie czynnych inicjatorów przygotowania i wydania imionników. Świadczy o tym zapis w tomiku dedykowanym Karolowi Gabrielowi Schmidtowi i Jakubowi Michałowi Schmidtowi ${ }^{138}$. Tu uzupełnienie: w niektórych sztambuchach poda-

${ }_{128}$ Dem Wohledlen und Wohlgelahrten Herrn Johann Michael Friederich Mundt, der Gottesgelahrtheit rïhmlichst befließenen. Bei Seiner Abreise von unsern akademischen Gymnasium nach der hohen Schule zu Jena von Seinen Freunden gewidmet. Übergeben von Dallmer und Goll. Im April 1784, Danzig [1784]. Egz. BG PAN, sygn. Oe 8700 $8^{\circ}$.

${ }_{129}$ Ksiega wpisów, op. cit., s. 357.

130 Ibidem, s. 358-364.

131 Dem Herm Ernst Benjamin Badengoth bey Seiner Abreise auf die Universität Königsberg. Im Septembermonat 1797, Danzig [1797]. Egz. BG PAN, sygn. Oe $778^{\circ}$ adl. 14.

132 Ksiega wpisów, op. cit., s. 372.

133 Ibidem, s. 368, 372-374.

134 Ibidem, s. 339.

135 Ibidem, s. 345 .

136 Ibidem, s. 365.

137 Gefihle und Ausdrücke inniger Freundschaft, Bey der Abreise unseres Lieben, Friedrich Deschner, der Gottes Gelahrtheit Beflissenen, auf die Academie Göttingen, im Namen aller überreicht von J. G. Schaal, J. E. Andreae und W. G. Fluge. Im September 1788, Danzig [1788]. Egz. BG PAN, sygn. Oe 70 $8^{\circ}$ adl. 8. — Ihren Verehrungswürdigen Freunden Herrn Johann Renner der Gottesgelartheit und Herrn Karl Renner der Rechtsgelartheit rïhmlichst Beflissenen widmen folgende Zeilen bei Ihrer Abreise nach Halle Innenbenannte. Danzig im Aprilmonat des Jahrs 1760, [Danzig 1760]. Egz. BG PAN, sygn. Oe $91782^{\circ}$. - An Herm Joachim Wilhelm Weickhmann, der Rechte und schönen Wissenschaften rïhmlichst Beflissenen bey Seiner Reise nach Wittenberg zum Denkmahl ihrer Freundschaft von Innengenannten. Danzig im Herbstmond des 1758sten Jahres, [Danzig 1758]. Egz. BG PAN, sygn. Oe $642^{\circ}$ adl. 114.

138 Unsern thetsersten Fretunden Herm Carl Gabriel Schmidt und Herrn Jacob Michael Schmidt der Rechte rühmlichst Beflissenen bey Ihrer Abreise nach der Universität Göttingen von Ihren Commilitonen zum Geneigten Andenken gevvidmet und besorgt von J. W. Weickhmann und P. G. Engelcke, Danzig 1788, im Monath September, [Danzig 1788]. Egz. BG PAN, sygn. Oe $608^{\circ}$ adl. 33; Oe $754^{\circ}$ adl. 8. 
wano imiona i nazwiska inicjatorów ich opublikowania, tych, którzy nad wydaniem czuwali, nie ograniczyli się zatem tylko do autorskiego uczestnictwa w tym edytorskim przedsięwzięciu. Dowód: na odwrocie karty tytułowej na przykład walety przeznaczonej dla Jerzego Ludwika Kummera poniżej dedykacji widnieją słowa: „überreicht von Johann Karl Alberti, Arthur Payne, Karl August Stelter". Tak jest również w zbiorku dla Deschnera. Tu na stronie tytułowej znajdujemy taki zapis: „überreicht von J. G. Schaal, J. E. Andrea und W. G. Fluge”.

Adresaci imionników nie zawsze byli uczniami Gimnazjum Gdańskiego. Oto drukowanymi sztambuchami obdarowani zostali Konstanty Ernest Groddeck i Jan Wilhelm John $^{139}$, spośród których tylko drugi figuruje w metryce gimnazjalnej ${ }^{140}$. Identycznie jest w wypadku druczku dedykowanego Beniaminowi Benedyktowi Henrichsdorfowi i Natanowi Gotfrydowi Möringowi ${ }^{141}$. Wypadnie powtórzyć: tylko drugi z nich był uczniem Gimnazjum $^{142}$. Nie należał do grona uczniów również Krystian Bogumił Duisburg, któremu przyjaciele dedykowali dwukartkowy druczek ${ }^{143}$. Natomiast autorzy tekstów rekrutowali się, jeśli nie wszyscy, to w części, spośród uczniów Gimnazjum. Oto niektórzy z nich: Jan Michał Wulff, Joachim Wilhelm Weickhmenn, Michał Waszkowizt, Karol Beniamin Raschke, Jan Beniamin Schmidt, Jan Adam Tritt, Karol Renner, Fryderyk August Deschner, Jan Bernad Gregorovius, Jan Daniel Schutz. Daniel Ehrgott Hansch, Jan Wilhelm Günther, Jan Bogumił Schnaase.

Czas zająć się zawartością drukowanych sztambuchów, rzecz jasna inaczej zaprojektowanych niż quodlibet monofoniczny zamykający w sobie — przypomnijmy — jeden tylko utwór: kantatę, propemptikon lub list.

Niektóre spośród interesujących nas tutaj imionników polifonicznych otwiera motto, umieszczone na odwrocie karty tytułowej. Oświetla ono najczęściej intencje inicjatorów ich wydania i autorów poszczególnych tekstów. Przyjmowało niekiedy formę apostrofy:

Trennung wie bist du so schwer!

powtarzającej się w kilku zbiorkach — zawsze w funkcji wypowiedzi inicjującej album amicorum. Identyczny charakter - ale wyrażone w zdaniu oznajmującym - ma motto otwierające zbiorek dedykowany Karolowi Gotthielfowi, Gronertowi i Janowi Michałowi Langwaldowi:

\footnotetext{
${ }_{139}$ An die [...] Herrn Constantin Ernst Groddeck und Herrn Johann Wilhelm John, als Sie um Ihre Bemühungen in des Rechtsgelahrtheit und Arzney-Wissenschaft weiter zu bringen, am 24sten May des 1757 sten Jahres nach Leiden abgiengen, zum Zeugniß ihrer Freundschaft von Innengenannten, Danzig [1757]. Egz. BG PAN, sygn. Oe $642^{\circ}$ adl. 75.

${ }^{140}$ Ksiegga wpisów, op. cit., s. 338.

${ }^{141}$ Bey der Abreise des Herrn Benjamin Benedict Henrichsdorf und Herrn Nathanael Gottfried Möring, von hier nach Rostock, Ihre Bemühungen in der Gottesgelahrheit weiter zu bringen von einigen Freunden. Im Monat Julius 1758, Danziq [1758]. Egz. BG PAN, sygn. Oe $642^{\circ}$ adl. 112.

${ }_{1+2}$ Ksiega u'pisów, op. cit., s. 339.

${ }^{143}$ An Herrn Christian Gottlieb Duisburg der Gottesgelahrtheit Beflissenen bey Seiner Reise nach Halle von innenbenannten Freunden. Danzig, im Aprill-Monat des 1758sten Jahres, [Danzig 1758]. Egz. BG PAN, sygn. Oe $642^{\circ}$ adl. 104
} 


\section{Das bitterste in der Natur ist - Trennung;}

Das süsseste - Wiedervereinigung.

Motto niosło $z$ sobą niekiedy życzenia. Znajdujemy je na przykład w imionniku poświęconym Janowi Krystianowi Ayckemu:

Auch in Göttingen denk' an uns.

Do tych słów dodano jeszcze:

Besonders an Deine Freunde, die Sammler dieses Quodlibets

J. H. Weickhmann, P. H. Zernecke.

Zdarzało się też motto refleksyjne. Przytoczmy jeden przykład - z tomiku dedykowanego Janowi Karolowi Friesemu:

Gott allein giebt, der Mensch

kann nur - wünschen.

Motto pozostawało zawsze w kręgu tych samych tematów: rozstania, trwania w pamięci, ludzkich pragnień - trudnych do spełnienia.

Liczną grupę stanowią zbiorki, w których motto nie występuje. Twórcy tych tomików funkcją wprowadzenia obdarzyli teksty stojące na czele licznych dalszych wpisów. Nie podpisane, a więc nie mające nic wspólnego $z$ autorstwem jednostkowym, anonimowe, miały stać się wypowiedzią o szczególnej doniosłości, bo wydobywającej to, co w całej walecie najważniejsze. Wiersz otwierający na przykład imionnik poświęcony Absalonowi Fryderykowi Marxowi traktuje o przyjaźni:

\section{Nichts auf Erden kömt dir gleich \\ Süsser Freundschaft Himmelreich! \\ Keine Wonne ruft wie du \\ Hohen Muth dem Menschen zu.}

Waletę dla Karola Beniamina Barendta i Karola Efraima Roepella otwiera prozaiczny tekst - tym razem podpisany (przez Schimminga):

Dem Gebrauch zufolge soll ich also in gegenwärtiger Sammlung, wo sich Freunde und Bekante Euer Andenken zu erhalten bemühen, der erste seyn, der Euch sein Abschiedskompliment darbrächte. Ich weiß mich aber nicht groß mit den Komplimenten zu befassen, überdem glaube ich unter die Zahl Eurer Freunde zu gehören; und eben deswegen werd't Ihrs auch nicht übel nehmen, wenn ich hier nichts weiter hinzusetze als den aufrichtigen Wunsch - Euch bald gesund und froh wieder zu umarmen. Dieser mein Wunsch aber soll mir, so Gott will, nicht lange unerfüllt bleiben. 
Przytoczony tekst napisany został według reguł retorycznych, pełni funkcję swoistego prooemium z uwzględnieniem captatio benevolentiae (skromność podmiotu, ograniczone możliwości podołania zadaniu) i docilitas, tu przyjmującą postać zapowiedzi tego, co w tekstach całego zbiorku zostanie niejednokrotnie zamanifestowane: życzenia powtórnego spotkania z wyjeżdżającymi na studia.

Zamknięcie tomików bywa bardziej urozmaicone. Zbiorek przeznaczony dla Karola Ernesta Kositzkiego i Filipa Adolfa Lampego kończy się cytatem z Lessinga:

Wir möchten gern dem Kritikus gefallen:

Nur nicht dem Kritikus vor allen.

Warum? Dem Kritikus vor allen

Wird auch kein Sinngedicht gefallen.

Cytat ten nie został przez nikogo podpisany, nie pełni więc roli wpisu pro memoria. Twórcy tomiku wyznaczyli mu inne zadanie: zamknięcia, i to zamknięcia nobilitującego zawarte w imionniku teksty.

Tomik dla Krystiana Bogumiła Perschkego i Jana Fryderyka Steinhöfela kończy epigram podpisany — nieco żartobliwie — przez Danzigs Musensitz:

Freunde!

Da Ihr nach Minervens Tempel ziehet,

Wo Geschmack und höhre Weisheit blühet;

Reiset wohl: Mehrt Wissenschaft und Witz.

Unsre Wünsche werden Euch begleiten.

Denkt an uns nach längst verstrichnen Zeiten.

Denkt an

Danzigs Musensitz

Waletę przeznaczoną dla Henryka Jakuba i Jana Bogumiła Martensów kończy zwięzły prozaiczny tekst, również nie pozbawiony intencji ludycznych:

Ich bin der Wegweiser und Steuermann des Menschen, unter meiner Aufführung allein kann er die Felsen vermeiden und die den Hafen gelange. Ich mache ihn vollkommen, nehmlich weise

die Weisheit

Natomiast tomik adresowany do Marxa kończy się często w tego typu zbiorkach pieśnic pożegnalną (Abschiedslied), w której powracają motywy rozstania (łzy rozstania), rozstanic z miastem, obecne w całym imionniku. Pieśn - nie podpisana - pomyślana została jakc ostatnie słowo wypowiedziane tuż przed wyruszeniem w drogę. Jej zakończenie jest pogod. ne, a życzenia w nim zawarte wolne od nostalgicznych westchnień i sentymentów:

Und nun, leb' wohl, Gott segne Dich, Marsch! hurtig h'rein in Wagen; 
Kein Zandern mehr, wer muß, der muß,

Nimm noch den letzten Scheidekuß,

Und nun - Glück auf die Reise.

Właśnie pieśń bodaj najczęściej występuje w roli elementu zamykającego sztambuchy. W tomiku dedykowanym Karolowi Beniaminowi Barendtowi i Karolowi Efraimowi Roepellowi znajdujemy Lied eines braven Studenten, pieśń podpisaną przez Adolfa Freiherra von Knigge. Zaczyna się ona apostrofą:

Freude, Freude sey mein Lied!

Kummer müsse weichen!

Nastrój pogody i radości, widoczny w początkowych wersach, utrzymuje się w całej pieśni, także w partiach refeksyjnych:

Was nütz Reichthum, Rang und Gut,

Gold in grossen Haufen?

Froher Muth, gesundes Blut,

Läßt sich doch nicht kaufen.

Przytoczmy jeszcze jedną zwrotkę:

Immer lacht der Himmel nicht;

Aber durch das Wölkchen

Scheint doch oft ein Strahl von Licht

Auf ein frohes Völkchen...

Niektórym pieśniom, noszącym - uzupełnijmy - z reguły miano Rundgesang, a więc przeznaczonym do śpiewania na przemian (kolejno) przez różne osoby, towarzyszy wskaźnik melodii. Przykład znajdujemy w liber memoralis Karola Gotthielfa Gronerta i Jana Michała Langwalda, w którym powołano się na — zapewne wówczas popularną — pieśń Die Zeiten, brïder, sind nicht... W ten sposób tekst zamykający waletę stawał się przekazem dwukodowym.

Do utworu kończącego Denkmal der Freundschaft dodano nawet nuty opatrzone wskazówką dla wykonawców: „Mit frölicher Laune und schnell”. Również Serenate im Walde zu singen, zawarta w tomiku przeznaczonym dla Jana Bogumiła Steltera i Samuela Leopolda Schimminga, bardzo radosna, młodzieńcza, z pochwałą wiosny i młodości, została wyposażona w material nutowy.

Rundgesang był także przewidziany do wykonania w trakcie tańca. Świadczyć o tym może następująca zwrotka pochodząca z thesaurus amicorum Jana Michała Fryderyka Mundta:

Wer aber leichte Beine hat

Und fest und sicher tritt

Und Brust und freyen Athem hat

Der, Brüder, laufe mit. 
I jeszcze końcowa strofa z tej samej pieśni:

Jetzt einen Handschlag, einen Kuß

Und sonst kein Wörtchen mehr

Es spreche Handschlag, spreche Kuß:

Gott walte um Euch her.

Nie sposób nie zauważyć, że pieśni zamykające zbiorki są na ogól pogodne, pełne radości. Rundgesang z tomiku dla Karola Jana Fryderyka von Rosenberg Gruszczynskiego narodził się wręcz pod znakiem epikureizmu:

Auf? laßt uns noch so lang' es geht,

Epikuräern gleichen.

Laßt Brüder! laßt die edle Zeit

In Fröhlichkeit verstreichen,

Und kommen Sorgen, Noth und Müh,

So schütteln wir - so fallen sie

Tief in des Meeres Abgrund.

W pieśni tej znajdujemy także myśl, którą również inni autorzy chętnie przywoływali:

[...] wer nicht liebt Wein, Weib, Gesang,

Der bleibt ein Narr sein Lebenlang.

Probat fand's Doctor Luther.

W pieśni kończącej sztambuch Jana Krystiana Ayckego dosłuchać się można również epikurejskich tonów:

Auf Brüder! auf! der Abschiedstag

Beängstigt unser Herz!

Auf! Singt zum hellen Becherklang,

Den letzten frölichen Gesang,

Bey frohem Spiel und Scherz!

Zamykający waletę adresowaną do Abrahama Fryderyka Blecha i Krystiana Bogumiła von Schrödera Lied bei der Begleitung unsrer Lieben zu singen, złożony z trzech zwrotek 6-wersowych (aacddc), napisany został w stylu poezji Anakreonta, śpiewaka miłości, młodości i wina. Oto pierwsza zwrotka:

Wir bringen mit dem Lebewohl,

Die Flasche altes Rheinweins voll,

Umkränzt von unsrer Freude;

Schenk' ein, schenk' ein bis auf den grund,

Und laßt uns unsern heil'gen Bund

Aufs neu' beschwören heute! 
W finalnych utworach pojawiały się niekiedy także tematy poważniejsze. Wiersz ze zbiorku ofiarowanego Janowi Michałowi Kiepkemu i Janowi Henrykowi Schmidtowi podejmuje zagadnienie przemijania:

Des Lebens zu genissen ist Freunde unsre Pfilicht. Durch Lust es zu versüssen verbeut die Tugend nicht. Bald ist der Lenz verblüht, bald schalt kein frohes Lid mer durch di Blumen Bäte, wo izt die Rose blüht.

Auch fliht der Lenz des Lebens

mi jedem Augenblik.

Ist er entflohn, vergebens

flehn Wünsche in zurük.

Euch sei di Stunde wärt, di heute Euch gehört; wer weis? ist morgen wider

Euch Freud und Freund gewärt ${ }^{144}$.

i ujmuje je w kategoriach szkoły stoickiej i epikurejskiej. Autor wiersza opowiada się - jak stoicy — za życiem zgodnym z naturą, dokładniej: $\mathrm{z}$ rozumem, za modelem życia łączącego — na wzór epikurejczyków — przyjemność z rozsądnym umiarem.

Utwór Am Trennungs-Abend, kończący waletę dedykowaną Pawłowi Schnaasemu, jest pieśnią na trzy głosy i chór, w której pierwszoplanowe miejsce zajmują rozważanie o przyjaźni (,Freundschaft ist von kurzer Dauer”), o rozstaniu („Wunden, die die Trennung schlug, Sind gezählt in Gottes Buch") i braterstwie. Trost in einer trïben Stunde, zamykajacy zbiorek, który na pożegnanie otrzymał Jan Ludolf Ratzki, zawiera skargę na samotność człowieka, na niestałość jego losu:

Bald verrirrt sich einsam unser Fuß

In ein Labyrinth voll Kummer und Verdruß.

Człowiek żyje w labiryncie kłopotów i zmartwień, jest pielgrzymem, dla którego

Grab und Staub das Ziel und Ende sind.

Odpowiedź na wszystkie pytania, rozwiązanie wątpliwości znajdzie spotkawszy się z Bogiem:

${ }^{144}$ Zachowano ortografię oryginału - jak zresztą we wszystkich cytatach. 
Dort erfahren sie, wie gut und weise

Gott des Schicksals dunkle Wege lenkt,

Und warum er auf den Weg der reise

Oefters eine schwere Nacht des Kummers senkt.

Motto, teksty wierszowane i prozaiczne otwierające walety; cytaty, żartobliwe epigramy, pieśni pożegnalne, Rundgesang, wiersze refleksyjne tworzyły ramy poszczególnych imionników. Oczywiście - nie bez wyjątku, zdarzały się bowiem tomiki tych ram pozbawione. Trzeba podkreślić, że teksty składające się na ramę doskonale wprowadzały w lekturę wpisów dokonywanych przez przyjaciół i kolegów i jednocześnie znakomicie wydobywały - w zakończeniu - to, co w sytuacji rozstania można było uznać za najważniejsze: dawały świadectwo przyjaźni, życzliwości i serdeczności okazywanej adresatom sztambuchów.

Utwory składające się na ramę walet napisane zostały po niemiecku. Odstępstw od tej zasady znajdzie się niewiele. Do takiego wniosku prowadzi lektura nie tylko utworów tworzących ramę, ale i wszystkich zapisanych w imionnikach. Do połowy XVIII stulecia konkurowała z tym językiem łacina, a nawet francuszczyzna. Później niemiecki zdobył widoczną przewagę. Wpisy hebrajskie czy greckie należały do rzadkości, nieczęsto zdarzały się też wpisy w takich językach, jak szwedzki, holenderski, włoski, angielski, węgierski i polski. Niektórzy autorzy popisywali się znajomością gwary dolnoniemieckiej (Niederdeutsch, Plattdeutsch), a w pochodzącej z połowy XVIII wieku walecie dedykowanej Filipowi Sylwestrowi Lürseniusowi i Karolowi Joachimowi von Behrowi znajdujemy makaron łączący właściwości niemieckiego języka literackiego, gwary dolnoniemieckiej i języka francuskiego:

Wie? Was? Mes chers amis! Szie wollen reißen fort?

Parbleu das iß zu toll. Je souhaite Vous kein kut Ort,

Warumb? Szie laßen mik hier pauvre diable allein,

Kewiß Messieurs! Dieu die drengk durk Mark durk Bein.

Dok weil nik moglik is daß ik dies ihndern kan,

Szo nehm Szie denn von mir die kleine Wunschke an:

Messieurs mes chers amis! Szie leb contents! Szie blüh,

Szie ler übsche vil auf Ihr Academie!

Ein kute Freund a cet écrit

Welker mak kein Ceremonie

Skoro jesteśmy przy popisach lingwistycznych, przytoczmy z walety ofiarowanej Karolowi Gotthielfowi Gronertowi i Janowi Michałowi Langwaldowi taką oto osobliwość ortograficzną:

Allekenntnißdiesichnuraufunsselbsteinschränketistverächtlichundeineitelnbetrachtungengewidmeteslebenistkeinleben

Odczytać ten tekst, zawierający zresztą poważną refleksję, należy następująco: 
Alle Kenntniß die sich nur auf uns selbst einschränket ist verächtlich und ein eiteln Betrachtungen gewidmetes Leben ist kein Leben.

W ten sposób od ramy zbiorków przeszliśmy do pozostałych wpisów, nieraz bardzo licznych, dochodzących do kilkudziesięciu, raz obszernych, kiedy indziej niewielkich rozmiarów.

Zacznijmy od cytatów. Znajdzie się ich niemało i w najdawniejszych, i w późniejszych waletach. Przyjaciele i koledzy wyjeżdzających na studia przywoływali Platona, Salustiusza, Tacyta, Pliniusza, Senekę, Wergiliusza i Juwenalisa. Wszelako najczęściej zaglądali do Horacego, jego pieśni refleksyjnych, do pełnych tęsknoty elegii Owidiusza i do Cycerona, w szczególności do takich jego pism, jak Laelius de amicitia, De officiis i Paradoxa Stoicorum. Cytowali nie tylko starożytnych, lecz także współczesnych autorów. Byli wśród nich Christian Fürchtegott Gellert, Ewald von Kleist, Gotthold Ephraim Lessing, Salomon Geßner, Christoph Martin Wieland, Friedrich von Hagedorn i Albrecht von Haller, szwajcarski anatom, fizjolog i botanik, a także poeta, wówczas wydawany i szeroko czytany. U wszystkich autorów, antycznych i nowożytnych, znajdowali refleksje o wiedzy i mądrości, miłości i przyjaźni ujmowanej niekiedy jako dzieło szczęśliwego wyboru, o przemijaniu i śmierci, rozważania znakomicie nadające się do powtórzenia w waletach, powstających zawsze w sytuacji rozstania. Cytat zastępował własną myśl, niekiedy inspirował do kształtowania własnych uwag i stawał się punktem wyjścia oryginalnej wypowiedzi. Zawsze tworzył intelektualne zaplecze imionników.

Obok cytatów wymienić należy maksymy czy sentencje — obiegowe, przy różnych okazjach przypominane. Tytułem przykładu przytoczmy następujące: „Quicquid corrigere est nefas levius sit patientia”; „Tempora mutantur et nos mutamur in illis”; "Si cor concordat, concordia corda coronat”; "Sapientia auro melior”; "Amicorum una est anima in duobus corporibus”; "Non omnia possumus omnes". Niektóre z nich wracały w ciągu lat w różnych waletach, chętnie powtarzane ze względu na uniwersalną wartość zawartych w nich myśli, stwarzając — jak cytat intelektualną aurę, tak charakterystyczną dla wszelkich wypowiedzi pochodzących ze środowiska akademickiego.

Wszelako zarówno cytaty, jak i przypomniane tu maksymy stanowily margines dokonywanych w imionnikach wpisów. Przyjaciele i koledzy wyjeżdżających na studia mieli ambicje wypełniania pożegnalnych zbiorków własnymi tekstami — prozaicznymi i wierszowanymi. Do nich obecnie przechodzimy.

Niektóre wpisy — prozaiczne, bo od nich zaczynamy — wyróżniają się wyjątkową zwięzłością. Sprowadzają się niekiedy do jednego słowa: „Valete”! Przyjmują także postać pytania: „Wird in Europa wohl ein Herz so edel seyn?”, pytania szczególnego, bo niosącego z sobą pochwałę osoby, do której się odnosi. Część wpisów obejmuje wyłącznie życzenia zamknięte w kilku zaledwie słowach: „Reisen Sie glïckich und behalten Sie mich lieb”. Do tej formuły — dość częstej - dodawano jeszcze życzenia spełnienia pragnień i oczekiwań. W sąsiedztwie życzeń wymienić należy pozdrowienia. $\mathrm{Z}$ walety przeznaczonej dla Gronerta i Langwalda wynotujmy taki przykład: „Pozdrawiaja cię, ktorzy sq ze mna wszyscy. Pozdrow tych, ktorzy nas mituja, $w$ Itallie". 
Typowe dla walet, będących (okazja, by o tym przypomnieć) drukowanymi imionnikami, są wpisy pro memoria. W tomiku przeznaczonym dla Jana i Karola Rennerów Bogumił Adrowski z Brodnicy, od 1757 roku uczeń Gimnazjum Gdańskiego ${ }^{145}$, zamieścil następujący tekst:

Uznanie prawdziwej człowieka godności i w tych przymiotach upodobanie, które więcej przez skrytą approbacyją rozumu i sumienia niż przez powszechne podżewienie odnoszą nadgrodę; to skarb, to szczęśliwość, to zasługa!

Inne wpisy pro memoria przypominają maksymy:

„Freundschaft versiüßt das Leben; Tugend belohnt sich selbst”; „Der Menschheit gröstes Glïck ist Zärtlichkeit und Tugendu”; „Nur der allein ist wahrhaftig glïcklich, der tugendhaft ist und einen Freund hat”; "Sey nie zu ängstlich für die Zukunft besorgt, denn Gott sorgt für uns alle”; „Die wahre Weisheit des Lebens ist — Leiden mit Wonne zu mischen”; "L'amour propre est captieux, il s'en faut défier; il est dangereux, parce que c'est lui, qui est la source de tous nos déréglemens". Zdarzają się też wpisy — pro memoria - mające formę pouczenia i ostrzeżenia: „Ein wahrer Freund ist ein hellglänzender Edelgestein in der Krone der Menschheit, darum wern Ihr einen habt, so achtet ihn hoch und sorget, daß Ihr ihn nicht verliehret”; „Traue nicht den Menschen, besonders den grossen, selten findest Du einen, der morgen noch an sein heut gegebenes Wort denkt”; "Damit Dich kein Schein blende, so hüte Dich vor syllogistischen Sande, denn er failt auf die Brust und Du bekommst Staub in die Augen...”; „Unsere heutige Philosophen sind Wegstangen, dei den Weg zeigen, ihn aber nicht gehen".

Przytoczone tu przykładowo wpisy pro memoria przypominają cytaty z autorów starożytnych i nowożytnych oraz maksymy o rodowodzie przeważnie antycznym. Pozostają w kręgu cnoty, przyjaźni, miłości, szczęścia, mądrości. Refleksje z tego obszaru powracały nie tylko w tych miniaturowych wpisach, lecz także w innych formach wypowiedzi, bardziej rozbudowanych, zwlaszcza w listach - pożegnalnych, bardzo osobistych. Ubolewano w nich z powodu rozstania, skarżono się na cierpienia wywołane rozłąką, lecz jednocześnie wyrażano nadzieję na możliwość podtrzymania przyjaźni lub jej odnowienia w przyszłości. Autorzy listów wyjazd przyjaciół czy kolegów — przy całym smutku i żalu — przyjmowali jednak ze zrozumieniem, wiedzieli bowiem, że jego celem jest świątynia Minerwy, są studia uniwrsyteckie. Oczekiwali ich powrotu do Gdańska „,mit derm Lorbeerkranze der Weisheit gekrönt”. Jeden z przyjaciół Jana Michała Fyderyka Mundta pisał: „Reise [...] glücklich, beschirmt von der Hand des Allgütigen und kehre einst mit nützlichen Kentnissen bereichert zu den Deinen zurück. In der Ferne aber denke an mich und bleibe mein Freund so wie ich der Deinige bin". Można się w tych słowach dosłuchać swego rodzaju konsolacji. Podobnie potraktować wypadnie wyrażaną w listach nadzieję na rychłe spotkanie za granicą, bo i żegnający przyjaciół wybierał się na studia. Konsolacja nie była jednak nigdy pełna. W listach — jak w innych wpisach pro memoria — raz po raz dawały o sobie znać refleksje pełne smutku i melancholii. Przyjaciel Absalona Fryde-

${ }^{145}$ Ksiega wpisów, op. cit., s. 345. 
ryka Marxa swój wpis zaczął od znamiennego pytania: „Was ist der Mensch? — Ein Ding, das alles sein will und nichts ist...".

Przechodząc do wpisów wierszowanych, odnotujmy najpierw, że są wśród nich niekiedy w zwięzłej formie podane - życzenia i słowa pożegnania. Najpierw przykład z tomiku Michała Wunscha, Jana Dawida Hankego i Daniela Hermana Richtera:

Reiset wohl geliebte Brüder,

Kommt gesund, gelehrter wieder.

Z Neues Taschen-Buch pochodzi ten osobliwy zapis, w intencji autora będący zapewne formą pożegnania:

A co to za halas na dworze?

Upiły się furmanowie na szczęśliwą drogę,

bo droga bardzo zła.

Bywają też życzenia rozbudowane, liczą niekiedy kilkanaście wersów. Tekst pochodzący z walety Abrahama Woltersa i Jana Henryka Martensa składa się z dwóch zwrotek:

Was ziehet Euch aus Danzigs Gründen?

Ists nicht Minervens Dienstbarkeit,

Bey der Ihr sucht Eur Glück zu finden,

Der Ihr Euch habt zum Dienst geweiht:

Ists also nöthig, daß man trauret,

Und Euren Abschiedstag bedauret,

Der Euch zum Ehrentempel führt?

Nein! reiset wohl, Ihr Musen-Söhne,

Des Himmels gütiges Geschick

Mach, daß der Fleiß Euch künftig kröne;

Ich wünsch Euch hiezu dieses Glück:

$\mathrm{Da} B$ man dereinst von Euch mag hören,

Wie Euch der Bürger Treu wird ehren,

Als Väter, deren Liebe wacht.

Całość ma charakter patetycznej wypowiedzi, w której królują pytania retoryczne i metonimie: „Minervens Dienstbarkeit” i „Ehrentempel” zamiast „studia”, „Musen-Söhne” zamiast "studenci”. Nietrudno w waletach, powstalych wszak w warunkach rozstania, o refleksje bardzo pesymistyczne:

Sie ist's nicht werth - so eine Welt wie diese

Daß man ihr eine Thräne weint --

Myśl ta pochodzi ze zbiorku przeznaczonego dla Karola Beniamina Barendta i Karola Efraima Roepella. 
Przykłady tu przytoczone prowadzą nas ku tekstom, które zajęły w omawianych imionnikach ważne miejsce. Chodzi o propemptika, a więc - o czym była już mowa - pieśni pożegnalne, w których pojawiały się najczęściej takie motywy, jak żal z powodu rozstania, prośba o pamięć kierowana do wyjeżdżającego, życzenia pomyślności i szczęśliwego powrotu.

Wcześniejsze propemptika pisano na wzór poezji bohaterskiej. Autorzy nie rozstawali się z wysokim stylem i z trzynastozgłoskowcem. Wiersz Krystiana Grama w liber memoralis Jana Rajnolda Hintza zaczyna się tak:

Es soll gereimet seyn. Wie muß man Verse messen?

Ich mag der Musen Hülf durch Betteln nicht erpressen...

Chętnie też przywoływano postacie ze świata antycznego. Przykład z tego samego tomiku:

Lebe Gelehrter! in steten Vergnügen,

Laß Pallas und Juno den Kummer besiegen,

Fliehe des Grames gefährliche Gränzen,

Laß Weißheit und Klugheit des Trennen ergänzen,

Nimm diese Gefährten nur mit Dich hinaus,

So bringst $\mathrm{Du}$ dieselben auch würklich nach haus.

Propemptika, i te spod znaku heroicznej konwencji, i te skłaniające się niekiedy ku sentymentalizmowi, należały do form wypowiedzi, w których obecność podmiotu była zawsze wyraziścic zaznaczona. W jednym $z$ wierszy umieszczonych $w$ walecie dedykowanej Flanderowi, Wichersowi i Reinickowi znajdujemy takie wyznanie:

So bleib ich ohne Freund, umringt vom Schwarm

Der Feinde! ach, und ich - ich bleib allein.

Karol Beniamin Feyerabend zwracając się do swoich przyjaciól — Schmidtów — tak pisał:

Ich glaub' Ihr Guten, daß wir uns verstehen,

Ists denn nicht hier, wo wir uns wiedersehen,

So wirds doch einst in bessern Welten seyn -

Da wird uns nichts, nichts von einander trennen,

Da werden wir uns ewig Brüder nennen,

Und uns hier angefangner Freundschaft freun!

W propemptikach — z tak wyraziście zaznaczonym ,ja" - skarżono się na rozłąkę, na samotność - w wrogim świecie; wyrażano wahania co do celowości wyjazdu przyjaciół i kolegów z Gdańska. Pisano o cnocie, o przemijaniu (i młodość ma swój kres!), o przyjaźni i miłości, o studiach i mądrości. Propemptikon z tomiku Jana Karola Friesego, napisany w formie dialogu, kończył się stwierdzeniem, że zgłębiający wiedzę nie powinien zapomnieć „Menschenkunde zu studiren”. Wracano do motywu rozstania, pisano o „Scheidestunde”, „Tren- 
nungstunde” („Ach schon naht die Trennungstunde...”), przedstawiano życie jako podróż. Autor wiersza dic Stationen des Lebens zamieszczonego w walecie Schmidtów zauważył:

Schon haben viel Dichter, die lange verblichen

Mit ciner Reise, das Leben verglichen:

Doch hat uns bis Dato, so weit mir bekannt,

Die Poststationen noch keiner genannt.

To zachęciło wspomnianego autora do napisania wiersza przedstawiającego kolejne fazy życia ludzkiego — od dzieciństwa do starości — jako podróży od stacji pocztowej do stacji. W tej samej walecie inny autor propemptikon zakończył następująco:

Ach! dann entfliehen die Kleinode des Lebens,

Gesundheit, Schönheit, Fröhlichkeit;

Dann wüschet er im Alter sich vergebens

Das Glöck der jugendlichen Zeit.

Przejdźmy do wpisów pro memoria - najbardziej dla walet charakterystycznych. Spotykamy w nich myśli, uwagi i obserwacje podobne do tych, z którymi stykaliśmy się w propemptikach. W tomiku dedykowanym Karolowi Gabrielowi Schmidtowi i Jakubowi Michałowi Schmidtowi znajdujemy między innymi dwie refleksje na temat cnoty, mądrości i przyjaźni:

Die Tugend folget stets der Weisheit hohen Plan,

Und unser wahres Glück sängt mit derselben an.

Freundschaft macht den Werth des Lebens,

Wer in ihr sein Glück nicht ehrt,

Lebt sich und der Welt vergebens

Und ist keiner Freude werth.

Refleksje tego typu przywoływano niewątpliwie z myślą o adresacie walety, choć nie nadawano im formy wypowiedzi bezpośrednio do niego kierowanej. Ze zbiorku adresowanego do Jana Michała Fryderyka Mundta wybierzmy ten dwuwers:

Wer das kann, was er will, ist ein glückseeliger Mann.

Doch weise und groß ist der, der das will, was er kann.

a z imionnika przeznaczonego dla Samuela Benedykta Flandera, Aleksandra Bertolda Wichersa i Gotfryda Eilharda Reinicka (Reincke) następujący tekst:

Durch Tugend müssen wir des Lebens würdig werden;

Denn ohne Tugend ist kein wahres Glück auf Erden,

Mit ihr ist niemand unbeglückt. 
W walecie poświęconej Gronertowi i Langwaldowi odżył znany topos theatrum mundi ze zmianą polegającą na zastąpieniu teatru operą:

Die Welt gleicht einer Opera,

Wo jeder, der sich fühlt,

Nach seiner lieben Leidenschaft

Auch seine Rolle spielt.

Der eine steigt die Bühn herauf

Mit einem Schäferstab,

Ein andrer, mit dem Marschallsstab,

Sinkt ohne Kopf herab.

Wir armer guter Pöbel stehn,

Verachtet, doch in Ruh,

Vor dieser Bühne, gähnen oft,

Und sehn der Fratze zu.

Die Kosten freylich zahlen wir

Fürs ganze Opernhaus;

Doch lachen wir, mißräth das Spiel,

Zuletzt die Spieler aus.

W jednym z wpisów zawartych w zbiorku dedykowanym Rennerom pojawia się przysłowie:

Ta najbogatsza skrzynia, co jest w głowie,

Jako hiszpańskie uczy nas przysłowie:

Że mądra głowa przez swoje staranie,

Czy kapelusza, czy czapki dostanie.

— w którym kapelusz i czapka są znakiem wyróżnienia, awansu będącego efektem wykształcenia, wiedzy ${ }^{146}$.

Teksty tak uniwersalnie pomyślane, nie uwzględniające w swojej strukturze konkretnego adresata, przeplatały się z wpisami bezpośrednio kierowanymi do opuszczających Gdańsk przyjaciół i kolegów. Mundt na przykład obdarowany został takim umoralniającym epigramem:

Freund, die Tage fliehen hin

Ehe wir sie noch geniessen,

Jede Stunde ist Gewinn,

$\mathrm{Laß}$ die Stunden nicht verfliessen.

${ }^{146}$ Por. polskie przysłowia: Jakby w czapce bobrowej chodził (tzn. uważa się za mądrego); Na czapkę patrzała, a chłopa wybrała. 
Podobny charakter — wypowiedzi z wpisanym adresatem — mają również inne teksty znajdujące się w waletach Mundta:

Folg nur der Tugend heiligen Wegen,

Die deinen Geist mit Ruhe krönt;

Nur sie verschaft Verehrern Seegen

Und fluchet dem der sie verhönt.

Flandera, Wichersa i Reinicka, a także Karola Beniamina Barendta i Karola Efraima Roepella:

Mettez votre gloire dans simplicité;

Que vos vertus et vos bonnes actions soyent

Les ornamens de vos personnes.

wreszcie Pawła Schnaasego:

Wenn's gleich ein bischen anders kümmt,

Als Du's in Gedanken hatt'st bestimmt,

Nimm all's vor gut, und sey zufried'n,

Mit dem, was dir dein Glück beschied'n.

Fryderyk Deschner znalazł w swojej walecie pochwałę cnoty:

Bild der Unschuld ist die Rose,

Sey ihr gleich; sey gut!

Tugend nur schenkt wahre Freuden

Und im Unglück Muth.

a Schnaase pochwałę pracy:

Arbeit ist des Lohnes Preis,

Arbeit ist das Salz des Lebens,

Und kein einz'ger Tropfen Schweis

Fließt für unser Wohl vergebens.

Immer laßt das matte Herz

Mit verstärkten Pulsen schlagen!

Niektórzy autorzy wpisów zastrzegali się, że przekazują swoje słowa „nicht als Lehren, sondern freundschaftliche Erinnerungen", lecz wielu z nich korzystało z okazji, by swoim przyjaciołom kilku rad i pouczeń udzielić. Przytoczone przed chwilą przykłady najlepiej o tym świadczą. U części autorów zauważyć można próby łączenia refleksji ogólnej, rozwijanej niezależnie od adresata, z uwagami powstałymi w ścisłym związku z jego osobą. Bodaj w dwóch waletach znajdujemy taką sentencję: 
Der eine hat den Beutel,

Der andre das Geld.

W album amicorum Schmidtów dodano żartobliwe uzupełnienie, adresowane - i to jest w tej chwili najważniejsze - właśnie do jednego z nich, po imieniu i nazwisku wymienionego:

Halt Du es mit dem letzten, mein Amicius, denn denkst so wie ich, und leb zufrieden und glücklich, doch nicht gar zusehr sonst möchtest Du deinen Freund vergessen.

Podobny tekst (podpisał go Jean Banjamin Matthesius. Etudiant en Theologie) z tomiku przygotowanego dla Henryka Jakuba i Jana Bogumiła Martensów:

La loi de l'amitié

Commande la fidelité

Et le Dieu de la constance

Ordonne cette observance

Chez le dernier Adjeu

Acceptéz encore mes voeux

Vivez heureux, toujours contens

Ce sont les voeux et sentimens.

Wyjątkowe miejsce wśród imionników zajmuje Noth-und Hülfs-Büchlein für Reisende, książeczka dedykowana von Schefflerowi, studentowi teologii. Koledzy udającego się do Królewca na studia nadali jej formę książeczki pomocniczej, której celem i zadaniem jest, o czym piszą w przedmowie, ułatwienie konwersacji podczas podróży i doradzanie w sprawach wynikających z różnych sytuacji — oczywiście pół żartem, pół serio. Oto jedna ze wskazówek:

Freund, Du eilest davon; so nim diese goldne Regel

Mit auf den Weg und vergiß nie Deines Freundes dabey.

Brauche weise die Zeit; sie eilt auf reissenden Fittig,

Aber genieße sie auch; halb nur lebtest Du sonst.

Wissenschaft machet uns groß, berühmt unsern Namen; doch wahre

Lebensphilosophie lehren uns Liebe und Wein.

Noth- und Hülfs-Büchlein zachowuje pozory publikacji adresowanej do szerszego grona odbiorców, zdaje się przypominać przewodnik dostępny dla wielu. W istocie jest jednak waletą mającą jednostkowego adresata - Schefflera. Upodobnienie tego pożegnalnego zbiorku do będących wówczas już w obiegu przewodników pozwala mówić o stylizacji; kto wie, czy nie o pastiszu realizującym żartobliwe intencje autorów?

Zart jest zresztą obecny w wielu tomikach. Humorystyczne i zarazem pełne wdzięku są zalecenia, które otrzymywali tacy adresaci walet, jak Jerzy Ludwik Kummer: 
Mosler Wein, der Sorgenbrecher,

Schaft gesundes Blut.

Trink aus dem bekränzten Becher

Glück und frohen Muth.

Jan Jakub Schalk:

Kein Doktor schwaze Dir die Brunnencuren ein,

Sey Dein selbst eigner Arzt, kurire Dich durch Wein.

Flieh Tropfen, flieh Mixtur, flieh Pulver, fliehe Pillen,

Durch Liebe und durch Wein verscheuche alle Grillen.

czy Absalon Fryderyk Marx:

Wird man alt und lebenssatt,

O! dennwird man herzlich matt,

Dies sagt Dir zum Abschied

Klatt

W tym ostatnim wypadku mamy do czynienia ze szczególnym rodzajem żartu, polegającego na włączeniu w przestrzeń rymową epigramu nazwiska autora wpisu ${ }^{147}$. W pewnym związku $\mathrm{z}$ tym utworem pozostaje epigram - tym razem $\mathrm{z}$ walety adresowanej do Jana Ludolfa Ratzkiego:

Gott laß alles Dir gedeyn,

Brod und Wasser, Fleisch und Wein,

Gebe Dir zu jeder Frist,

Was Dir gut und nüzlich ist.

Nun Amen.

Nie o rym tym razem chodzi, lecz o pointę, o owe: „Nun Amen”. Sakralna formuła amen - następująca po tekście należącym do sfery raczej profanum wywołuje efekt humorystyczny.

Takich miniatur znajdzie się w waletach więcej. Żeby nie być gołosłownym, przytoczmy tu kilka ze zbiorków dedykowanych Flanderowi, Wichersowi i Reinickowi:

Im grüen Thale sein Mägdgen küssen,

Von keinem Grame und Neide wissen,

Das ist schon Glück genug.

${ }^{147}$ Był nim Jan Erdmann Klatt, wpisany do metryki Gimnazjum Gdańskiego wraz z Marxem w 1780 roku. Ksiega wpisów, op. cit., s. 363. 
Karolowi Beniaminowi Barendtowi i Karolowi Efraimowi Roepellowi (dwa epigramy):

Il faut de tout en cette vie

bon vin, bons livres, bonne amie

et bonne chère et bon argent

bonne santé, le coeur content.

Ohne Lieb' und ohne Wein,

Was wär' doch mein Leben?

Alles, was mich kan erfreun

Müssen diese geben.

Will ich mich einmal erfreun,

Was ist meine Freude?

Nur mein Mädchen, ein Glas Wein,

Einzig diese.

Marxowi:

Ein Mädchen sehn, und nichts empfinden

Ist eine von den grösten Sünden,

Und ich - ich sündige nicht gern.

Ein artig Mädchen zu betrachten,

Und nicht nach ihrem Kusse schmachten,

Die Thorheit bleibe von mir fern.

Ratzkiemu (dwa epigramy):

Wer Freunde liebt, um nicht allein zu seyn,

Der nehm ein schönes Weib und halte guten Wein.

Laß den Taumelkelch nicht sinken

Der uns unsre Freyheit giebt,

Laßt uns bis zum Frohsein trinken;

Wer die edle Freyheit liebt.

Wem ein Burschenschmaus behaget,

Ey, der setze nochmahls an,

Bis der Abschieds-Morgen taget

Bis man nicht mehr jubeln kann.

Imionniki, z których cytaty te pochodzą, ukazały się w ciągu końcowego ćwierćwiecza XVIII stulecia. Już zewnętrznie różnią się od wcześnicj powstałych. Małego formatu, wyposażone zostały przez swego wydawcę, a był nim głównic Daniel Ludwik Wedel, w rokokowe miniatury graficzne. Z rokokiem wszelako łączy przypomniane tu teksty znacznie więcej. Uderza osobisty ton, poczucie bliskiej, partnerskiej więzi z odbiorcą, nastawienie na zart 
i zabawę, w konsekwencji odejście od klasycystycznej i barokowej oficjalności, w waletach w końcu dominującej, zaniechanie tak częstego w nich dydaktyzmu i zastąpienie go pochwałą uroków życia, wina, wesołej biesiady — w stylu epikurejskiej etyki, interpretowanej niekiedy w duchu hedonistycznym.

Uwagi te odnieść można nie tylko do miniatur literackich — do wspomnianych tu epigramów - lecz także do nicktórych pieśni, przypominających biesiadne i refeksyjne Carmina Horacego. Z tomiku Jana Karola Friesego, wydanego notabene w roku 1787, przytoczmy dwic początkowe zwrotki:

Lustig, lustig, immer zu

Lustig Heut und Morgen!

Lobe mir die süße Ruh,

Frage nichts nach Sorgen!

Stund und Tag, und Woch' und Jahr

Fliehn wie Augenblicke.

Lustig, lustig, denn fürwahr,

Keiner kehrt zurücke.

Pieśn (o rok późnicjsza od poprzedniej) ze zbiorku przeznaczonego dla Jana Krystiana Ayckcgo ma budowę ramową, a zaczyna się następującą zwrotką:

Beständig frohen Herzens seyn

Ist eine seltne Gabe;

Und wer sie hat, der kann sich freun

So einer seltnen Gabe.

kończy się zaś tak:

Und immer frohen Herzens seyn

Ist eine edle Gabe;

Und wer sic hat, stimm' laut mit ein:

Wohl mir, daß ich sie habe!

Zwrotka poprzedzająca ostatnią zawiera radę i zachętę skierowaną bezpośrednio do wyjeżdżającego na studia Ayckego:

Drum Lieber! laß uns thätig seyn

Durch unser ganzes Leben;

Denn Fleiß und Arbeit kann allein

Ein frohes Herz uns geben.

W tym samym album amicortum znajduje się pieśń zaczynająca się od słów „Auf, Bester! geniesse des Lebens" — takżc bliska tradycji epikurejskiej. Inny autor w wierszu zamieszczonym w tym imionniku zauważyl: 
Hofnung nährt den Unterdrückten

Aber Hofnung ist ein Traum!

Freundschaft! Freundschaft! Du allein

Stützest Lieb und Hofnungslose!

Freundschaft! Freundschaft! Du allein

Dringst durch Dornen — brichst - und reichest uns die Rose.

Jest w tych pieśniach i stoicyzm, i epikureizm, i rokokowy wdzięk.

Pod wieloma tekstami, zwłaszcza obszerniejszymi, poważnymi i ludycznymi, znajdujemy niekiedy objaśnienia czy wykładnię zawartych w nich myśli - tak zwane symbolum. Spośród wielu przytoczmy tu kilkanaście przykładów: „Ist Gott für mich, wer wag wider mich seyn; Amor vincit omnia”; „Freundschaft und Freyheit!”; "Wer viel fragt, dem wird viel geantwortet”; "Ich folge dem Schicksal”; „Was lange dauert wird gut”; „Allzuviel ist ungesund”; „Liebe ist ein Stäbchen zum Spazierengehn, Freunschaft ist ein spanisch Rohr aufReisen”; „Aut Caesar aut nihil; Semper idem”; "Glïck und Zeit ändern vieles”; „Fugit irreparabile tempus”; „Die Liebe ist blind; Essen und trinken hält Leib und Seel' zusammen”; "Experientia docet”; „Durch Schaden wird man klug”; „Folge der Tugend”; „Der Kluge redt wenig und denkt viel”. Będąc swoistym morałem czy pointą wiersza lub utworu prozaicznego, symbolum występowało przede wszystkim jako „coniectio seu coniectura rei unius ex altera" ${ }^{148}$, stanowiło ważne uzupełnienie myśli zawartych w tekście, do którego nawiązywało, ich interpretację, utrwalało znane skądinąd prawdy obiegowe.

Wszystkie imionniki, i te z początku wieku, i te z jego końca, były prawdziwymi pomnikami przyjaźni. Autorzy wpisów - zarówno ci, którzy skłaniali się ku stoicyzmowi, jak i ci, którzy występowali z hasłami epikurejskiej natury, zarówno ci, którzy przyjmowali pozy moralistów, jak i ci, których bawiła lekkość miniatury literackiej, dawali świadectwo swej życzliwości i serdeczności wobec adresata walety. Wszystko było jemu podporządkowane łącznie z dość często spotykaną formułą kończącą wpis, a charakterystyczną dla wszelkich sztambuchów: „Zum Andencken...”; „Dieses schrieb zum Andenken...”; „Schriebs zum immerwährendem Andenken”; „Mit diesen Zeilen empfiehlet sich...”; „Hiemit empfiehlet sich dem gïtigen Andenken”. A oto inne przykłady, należące również do tradycji sztabmuchowej: „Bei Lesung dieser Zeilen erinnert Euch, meine Lieben, Eures zurückgebliebenen Freundes”; „Bei Durchlesung dieser Zeilen erinnre Dich [...] Deines Freundes”; „Denken Sie bei diesen Worten an Ihren Freund”.

\section{Dopowiedzenie}

Waletom, którym poświęciliśmy te strony, towarzyszyły rękopiśmienne imionniki. Niektóre z nich znajdują się do dzisiaj w Bibliotece Gdańskiej ${ }^{149}$. Ich właścicielami byli ucznio-

148 T. Michałowska, Staropolska teoria genologiczna, Wrocław 1974, s. 187.

149 Katalog rękopisów Biblioteki Gdańskiej Polskiej Akademii Nauk. Uzupelnienia do tomów I-IV (Sygnatury 1-4258) oprac. P. Szafran, Wrocław 1988. - Por. też J. Muhl, Das Stammbuch des Senators Abraham Ludwig Muhl au: Danzig (1782-1789), „Mitteilungen des Westpreußischen Geschichtsvereins” 1915, nr 4, s. 73-76. 
wie Gimnazjum Gdańskiego, późniejsi studenci: Karol Gotthilf Patzer ${ }^{150}$, Karol Gotfryd Schopenhauer ${ }^{151}$, Jan Gotthelf Schaal ${ }^{152}$, Daniel Fryderyk Rösner ${ }^{153}$, Piotr Bogumił Engelcke $^{154}$, Gotfryd Götz ${ }^{155}$. Wszyscy byli uczniami Gimnazjum Gdańskiego, a do jego metryki wpisani zostali w latach 1769-1788 ${ }^{156}$. Gdańszczaninem był również J. S. Thome, właściciel jednego z imionników ${ }^{157}$, jakkolwiek nazwiska jego w metryce gimnazjalnej nie znajdujemy. Wpisów dokonywali przeważnie przyjaciele i koledzy z lat nauki w Gimnazjum i studiów. W wielu wypadkach spotykamy się z osobami znanymi z drukowanych sztambuchów. Dość przypomnieć takie nazwiska, jak Cosak, Feyerabend, Gronert, Hacker, Kummer, Rosenberg Gruszczynski, Stelter, Weickhmann. Pojawiały się też nazwiska osób spoza tego grona. Wymieńmy tytułem przykładu rektora Gimnazjum Wilhelma Pawła Ver Poortenna, Amalię Justynę Renatę Cosak czy Florentynę Renatę von Schroeder.

Wpisy pro memoria w niektórych imionnikach poprzedzone zostały przez dedykacje, najczęściej zwięzłe, jakkolwiek zdarzały się też bardziej rozbudowane. Dedykacja Götza, datowana w marcu 1792 roku, jest skromna: „Seinen Freunden widmet diese Blätter...” Engelcke posłużył się znanym również z sztambuchów drukowanych określeniem Denkmahl der Freundschaft. Podobnie postąił bliżej nie znany ${ }^{158}$, ale pochodzący z Gdańska I. G. Thome, którego imionnik nosi tytuł Denkmale der Freundschaft, dedykacja zaś ( $z$ takim oto oznaczeniem miejsca i roku: Breslau 1760) otrzymała nastąpujące brzmienie:

Hier wil jetzt meine Pflicht der Freundschaft Denkmal' bauen;

Hier soll ein wahrer Freund, sich stets unsterblich schauen;

Ein Herz das tugendhaft, erhaben und getreu,

Das falsche Liebe meid't, von schnöden Lastern frey.

Soll als das höchste Gut der Erden,

Hier jederzeit bewundert werden.

Nadawcą dedykacji był we wszystkich podanych tu przykładach właściciel imionnika, adresatem zaś wpisujący się przyjaciel, kolega, profesor czy nauczyciel. Dedykacja zastępowała — oczywiście tylko w pewnym zakresie — ramę walety, stanowiące ją teksty, jak motto, cytaty, żartobliwe epigramy, pieśni pożegnalne, wiersze refleksyjne. Już to pozwala mówić o podobieństwie omawianych w tej chwili imionników i drukowanych sztambuchów. Punktów stycznych znajdzie się zresztą więcej — od różnojęzyczności (z dominantą łaciny

\footnotetext{
150 Syngatura jego imionnika: Ms. 1136 I.

151 Syngatura jego imionnika: Ms. 1175 I.

152 Sygnatura jego imionnika: Ms. 1414 I.

153 Sygnatura jego imionnika: Ms. $1191 \mathrm{I}$.

154 Sygnatura jego imionnika: Ms. 1129 I.

155 Sygnatura jego imionnika: Ms. 1418 I.

156 Ksiega wpisów, op. cit., s. 347-370.

157 Sygnatura jego imionnika: Ms. 1122 I.

158 Nie udało się rozszyfrować nawet jego imion.
} 
i języka niemieckiego) poczynając, a na doborze cytatów (z Cycerona, Horacego, Gellerta), maksymach czy sentencjach, wierszach refleksyjnych i żartobliwych, na wpisach pro memoria prozą, na poincie w formie symbolum (na przykład: toujour content) kończąc.

W niektórych imionnikach znajdujemy pejzaże wykonane techniką akwarelową, a album amicorum Rösnera zawiera nawet haft. Spotkać również można ozdobne ramki i winiety. Na złoconych grzbietach dwóch imionników - Götza i Engelckego — znajdujemy, co tu szczególnie interesujące, plakietki ze złotym wyciskiem: „Sacrum amicis” i „Der Freundschaft heilig”. W ten sposób raz jeszcze powrócił motyw przyjaźni. Powtórzmy więc: zarówno imonniki rękopiśmienne, których początki w Gdańsku sięgają XVI i XVII stulecia ${ }^{159}$, jak i drukowane sztambuchy były prawdziwymi pomnikami przyjaźni. Z perspektywy czasu dodajmy: pomnikami wysokiej kultury umysłowej, uczuciowej i literackiej młodych gdańszczan minionych wieków.

$\mathrm{Na}$ koniec dwa zupełnie wyjątkowe wiersze związane z gdańskim środowiskiem uczniowskim. Adresowane do Karola Ludwika Schreibera (zm. 1770), ucznia Gimnazjum Gdańskiego od 1739 roku $^{160}$, syna znanego i cenionego nad Motławą drukarza, Tomasza Jana Schreibera (1699-1778), ukazały się w roku 1748, gdy Karol Ludwik, w przyszłości założyciel drukarni w Gdańsku przy ul. Tkackiej, otrzymał promocję do najwyższej klasy Gimnazjum i jednocześnie wyzwolony został na towarzysza sztuki typograficznej. Jeden wiersz podpisał „verbundenster Diener" 161 , drugi podpisali „die in der Schreiberischen Kunststätte gegenwärtig befindlichen Glieder" ${ }^{162}$. Oba przyniosły pochwałę wiedzy i mądrości, sztuki drukarskiej i Gutenberga; wynosiły Karola Ludwika, który połączył naukę z umiejętnościami typografa („Mit denen Studien die Druckerkunst vereint") - niczym Robert Stephanus z Paryża i Genewy oraz Aldus Manutius z Wenecji. Dzisiejszy uczeń Gimnazjum będzie wkrótce znakomitym kontynuatorem dzieła ojca — również ta myśl dochodzi do głosu w obu panegirykach. Wszelako najbardziej rozbudowane zostały pochwały wiedzy i umiejętności, pracowitości i pilności, tych zatem wartości, które tak często powracały w uczniowskich i studenckich waletach.

159 Katalog rękopisów Biblioteki Gdańskiej Polskiej Akademii Nauk. Uzupetnienia do tomów I-IV (Sygnatury 1-4258), op. cit.

${ }^{160}$ Ksiega wpisów, op. cit., s. 327.

${ }^{161}$ Als der Wol-Ehrenveste, berïhmte und Kunsterfahrne Herr Thomas Johann Schreiber, eines Hochedlen und Hochweisen Raths und des weitberühmten Gymnasii zu Danzig wolangesehener Buchdrucker Seinen wïrdigen Sohn, den Wolgelahrten und Kunstgeübten Herrn Carl Ludwig Schreiber am 25sten des Heumonats 1748 zum Mitgliede einer Kunsterfahrnen Gesellschaft derer Buchdrucker erklärete wolte hiemit seine Ergebenheit bezeigen ein verbundenster Diener, Danzig [1748]. Egz. BG PAN, sygn. Oe $1712^{\circ}$ adl. 24.

${ }_{162}$ Als der Wolgelehrte und Kunsterfahrne Herr Carl Ludurig Schreiber den $16 t e n$ des Augustmonats in die öberste Classe eines weitberiihmten Gymnasii in Danzig versetzet wurde: auch den 25sten desselben Monats das gewöhnliche Postulat in Seines Herm Vaters Buchdruckerey verschenkte; statteten Demselben in nachfolgendem Gedichte ihren aufrichtigen Gliickwunsch ab die in der Schreiberischen Kunststätte gegenwärtig befindlichen Glieder, [Danzig 1748]. Egz. BG PAN, sygn. Oe $1712^{\circ}$ adl. 25 . 